\title{
Article
}

Doi 10.5943/mycosphere/8/10/11

Copyright $\odot$ Guizhou Academy of Agricultural Sciences

\section{Can ITS sequence data identify fungal endophytes from cultures? A case study from Rhizophora apiculata}

\author{
Doilom $M^{1,2,3,7}$, Manawasinghe $I^{1,3}$, Jeewon $R^{4}$, Jayawardena $\operatorname{RS}^{1,3}$, Tibpromma \\ $S^{2,3}$, Hongsanan $S^{3}$, Meepol $W^{5}$, Lumyong $S^{6}$, Jones BBG $^{7}$, Hyde KD $^{2,3,8}$
}

\author{
${ }^{1}$ Beijing Key Laboratory of Environmental Friendly Management on Fruits Diseases and Pests in North China, \\ Institute of Plant and Environment Protection, Beijing Academy of Agriculture and Forestry Sciences, Beijing 100097, \\ People's Republic of China \\ ${ }^{2}$ Key Laboratory for Plant Diversity and Biogeography of East Asia, Kunming Institute of Botany, Chinese Academy of \\ Science, Kunming 650201, Yunnan, People's Republic of China \\ ${ }^{3}$ Center of Excellence in Fungal Research, Mae Fah Luang University, Chiang Rai 57100, Thailand \\ ${ }^{4}$ Department of Health Sciences, Faculty of Science, University of Mauritius, Reduit, Mauritius \\ ${ }^{5}$ Mangrove Forest Research Center, Mangrove Conservation Office Department of Marine and Coastal Resources, \\ Ranong 85000, Thailand \\ ${ }^{6}$ Department of Biology, Faculty of Science, Chiang Mai University, Chiang Mai 50200, Thailand \\ ${ }^{7}$ Department of Entomology and Plant Pathology, Faculty of Agriculture, Chiang Mai University, Chiang Mai 50200, \\ Thailand \\ ${ }^{8}$ World Agroforestry Centre, East and Central Asia, Kunming 650201, Yunnan, People’s Republic of China
}

Doilom M, Manawasinghe IS, Jeewon R, Jayawardena RS, Tibpromma S, Hongsanan S, Meepol W, Lumyong S, Jones EBG, Hyde KD 2017 - Can ITS sequence data identify fungal endophytes from cultures? A case study from Rhizophora apiculata. Mycosphere 8(10), 1869-1892, Doi 10.5943/mycosphere/8/10/11

\begin{abstract}
Culture-based studies have recovered fungal endophytes from numerous plant hosts, while direct examination of sporulating cultures has enabled identification. However, many endophytes cannot be identified due to the fact that they only form mycelia sterilia in culture. Although next generation sequencing (NGS), as well as ITS sequence analyses have been used to identify endophytes, identification is still rudimentary. In this study, we isolated fungal endophytes from Rhizophora apiculata in Thailand and established how many can be identified to species level based on ITS sequence data. Endophytic fungi were isolated from leaves, petioles and aerial roots of $R$. apiculata in four provinces of Thailand. One hundred and fifty four isolates were obtained and initially grouped into 20 morphotypes based on cultural characteristics. Nine were sporulating morphotypes, which were assigned to seven genera (Colletotrichum, Diaporthe, Hypoxylon, Neopestalotiopsis, Neodevriesia, Pestalotiopsis and Phyllosticta), and eleven morphotypes were non-sporulating mycelia sterilia. Sequence similarity comparison and phylogenetic analysis of the ITS regions were further used to identify taxa. While ITS sequence data is reliable to assign isolates at the generic rank, and can be useful to identify taxa to species level in a small number of fungal genera, it cannot generally be used to determine specific species in most genera. ITS analysis classified 30 representative isolates into 20 taxonomic units residing in 15 known genera: Allophoma sp., Colletotrichum spp., Diaporthe spp., Hortaea werneckii, Hypoxylon griseobrunneum, Hypoxylon sp., Pestalotiopsis sp., Phanerochaete sp., Phyllosticta spp., Pseudopithomyces maydicus, Preussia sp., Nemania sp., Neodevriesia sp., Neopestalotiopsis sp.,
\end{abstract}


Rigidoporus vinctus, Schizophyllum sp. and one unidentified genus. Of the morphotypes, four were identified to species. The results from Blast searches and ITS phylogeny of the 15 genera and the one unidentified genus are discussed. Twenty-five of the 30 isolates could not be identified and thus an estimated 20 isolates are likely to be new species and one a new genus. This is remarkable, as endophytes of a single host in Thailand, may yield $75 \%$ or more of new species. This is not akin to the OTUs generated in NGS platforms, which are generally short sequences with high possibility to not match with sequences in GenBank, not because they are new, but because of the quality of the sequence data.

Key words - cultural characteristics - culture-dependent technique - ITS - mangrove morphotype - mycelia sterilia - phylogenetic analysis

\section{Introduction}

Rhizophora apiculata (Rhizophoraceae) is a mangrove tree species which occurs in the intermediate estuarine zone in the mid-intertidal region. The species is also widespread throughout most tropical coastal areas of the western Pacific region to east Africa (Duke 2006). Mangrove ecosystems play important roles in estuarine systems (Thrush et al. 2013). For example, the root system of $R$. apiculata serves as a habitat and nursery ground for numerous organisms, such as juvenile fish and crustaceans (MFF 2011). They also provide erosion mitigation and stabilization for adjacent coastal landforms (Harty 1997). Mangrove species also have potential to absorb and fix heavy metals (Lian et al. 1999, Ravikumar et al. 2007).

Endophytes are microorganisms, which colonize and live in internal plant tissues without causing apparent symptoms of disease to the host plant (Petrini 1991, Photita et al. 2001, Kumar \& Hyde 2004, Promputtha et al. 2005, Hyde \& Soytong 2008, Yoo \& Eom et al. 2012). Fungal endophytes are important in studies on plant ecology and evolutionary relationships as they can be latent pathogens, saprobes or beneficial symbionts (Photita et al. 2004, Rodriguez et al. 2004, Hyde et al. 2007, Promputtha et al. 2007, Sieber 2007, Slippers \& Wingfield 2007, Hyde \& Soytong 2008, Aly et al. 2010, Saikkonen et al. 2010, Thirunavukkarasu et al. 2011). Endophytes have possible uses in biotechnology as they can produce bioactive secondary metabolites, which have potential for anti-microbial and anti-cancer use (Chaeprasert et al. 2010, Devi et al. 2012, Joel \& Bhimba 2012, Job et al. 2015).

The traditional study and identification of fungal endophytes has been based on promoting sporulation of isolates growing out from sterilized asymptomatic plant tissues (Guo et al. 1998, Taylor et al. 1999). Many studies on endophytes have isolated strains which sporulate on different artificial media, under different cultural conditions (Carroll 1986, Paul et al. 2012). However, many do not sporulate in culture and are known as mycelia sterilia. This makes identification difficult. Thus several methods have been developed to stimulate sporulation of fungal endophytes, e.g. exposure at $20-25{ }^{\circ} \mathrm{C}$ under a 12 hours alternating near UV-light and darkness (Guo et al. 1998, Gomes et al. 2013) and transferring non-sporulating isolates to chemically defined media such as Czapek's agar, or on natural media such as corn meal agar (CMA), malt extract agar (MEA), oat meal agar (OMA), potato dextrose agar (PDA) and vegetable juice agar (V8A) (Paul et al. 2012). Sometimes growing mycelium of fungal endophytes with sterilized host substrates will induce sporulation (Guo et al. 1998, Taylor et al. 1999, Fröhlich et al. 2000, Gomes et al. 2013). Many taxonomic concepts have also been discussed for non-sporulating fungal isolates, e.g. grouping mycelia sterilia isolates into morphological species on the basis of similarity of cultural characteristics (Bills 1996). Isolates having similar cultural characteristics are grouped into the same morphotype, but such a taxonomic concept may be erroneous as isolates of the same morphotype may not be closely related (Guo et al. 2003).

Molecular based sequence data have also been used for phylogenetic placement of endophytic mycelia sterilia. Many studies have traditionally used sequence data from the ITS region to identify non-sporulating colonies and evaluate morphotaxonomic delimitation of endophytic fungi (Guo et al. 2000, 2001, 2003, Arnold 2002, Lacap et al. 2003, Promputtha et al. 2005, Tejesvi et al. 2011, 
Jeewon et al. 2013, Haghighi \& Shahdoust 2015). The internal transcribed spacer (ITS) region is the most widely sequenced genetic marker for fungi (Nilsson et al. 2008, 2014), and ITS has been formally proposed as the standard fungal barcode marker (Schoch et al. 2012, 2014). Comparisons of ITS sequence data are comprehensively used for molecular phylogenetic studies because the region is easy to amplify, even when small quantities of DNA are used, due to the high copy number of rRNA genes available in the genome (Haghighi \& Shahdoust 2015). ITS region is highly variable although with a few exceptions (Gazis et al. 2011, Lindahl et al. 2013).

The aim of the present study was to establish how many species of endophytes from a study of Rhizophora apiculata in Thailand can be resolved to species based on ITS sequence data. Rhizophora apiculata is commonly found in mangrove forests in Thailand. However, there are few reports on the species composition and biodiversity of endophytic fungi from Thai mangrove plants (Chaowalit 2009, Buatong 2010, Chaeprasert et al. 2010, Sakayaroj et al. 2010). Cultural characteristics were initially used to group the endophytes, while ITS sequence data was used to identify and establish if the endophytes can be assigned to species level.

\section{Materials \& Methods}

\section{Collection and isolation}

Plant samples of Rhizophora apiculata were collected from five sites in four provinces in Thailand (Chanthaburi, Phetchaburi, Prachuap Khiri Khan and Rayong Provinces). At each site, asymptomatic leaves, petioles and aerial tip roots were randomly collected and placed in separate brown paper bags. The samples were brought to the laboratory and when feasible isolated on the same day. Where necessary, samples were refrigerated at $4{ }^{\circ} \mathrm{C}$ and isolation was carried out the following day.

The isolation of endophytic fungi was adapted from Bharathidasan \& Panneerselvam (2011). Asymptomatic leaf, petiole and aerial stilt root samples were rinsed in tap water to remove debris and dirt. Root samples were cut into small pieces $\left(0.5-0.7 \mathrm{~cm}^{2)}\right.$ using a sterilized blade. Leaf samples were cut using a sterilized hole puncher size $6 \mathrm{~mm}$ diam. Petiole samples $(0.5-0.7 \mathrm{~cm}$ long) were cut using a sterilized blade. A total of 200 segments recovered from the different plant tissues (70, 70 and 60 segments of leaves, petioles and aerial stilt roots, respectively) were used. Each set of plant material was surface sterilized by slowly shaking for 1 minute in $3 \%$ sodium hypochlorite $(\mathrm{NaOCl})$ followed by a minute in sterile water. The samples were then disinfected in $70 \%$ ethanol for 1 minute followed by three rinses with sterile distilled water. The plant pieces were dried by blotting on sterile filter paper. Four to five segments were placed in each Petri-dish on water agar (WA) supplemented with $100 \mathrm{mg} / \mathrm{ml}$ streptomycin. The dishes were sealed with parafilm and incubated at $27{ }^{\circ} \mathrm{C} \pm 2{ }^{\circ} \mathrm{C}$ for one or two weeks at room temperature until the onset of fungal growth. Fungal colonies were selected and purified by transferring single hyphal tips daily onto potato dextrose agar (PDA) plates throughout a 2-week period. Pure cultures were maintained for further study on PDA. Living cultures of different isolates were deposited in the Mae Fah Luang Culture Collection, Thailand (MFLUCC).

\section{Comparison of cultural characteristics}

The cultural characteristics of each isolate were compared based on the morphotype concept (Bills 1996, Lacap et al. 2003). Five mm diameter plugs were cut from the edge of actively growing colonies and placed onto fresh PDA. Three replicates of each isolate were incubated in the dark at $25^{\circ} \mathrm{C}$. The average colony diameter $(\mathrm{mm})$ was determined after seven days. Colony characteristics, including colour (above and below), elevation, margin, shape and surface were observed after 14 days of incubation (Lacap et al. 2003). Colony colour was defined with the Methuen Handbook of Colour (Kornerup \& Wanscher 1967) and colonies photographed. Those cultures which sporulated on PDA after 1-2 months were identified based on morphological characteristics from general reference sources as mentioned in Doilom et al. (2017), and recent relevant literature.

\section{DNA extraction, PCR amplification and sequencing}


Twenty morphotypes of the 30 representative isolates (where available, 2-5 isolates from each morphotype) were selected for the molecular analyses. The selection was based on different cultural characteristics after purification. Total genomic DNA was extracted from fresh mycelium $\left(500 \mathrm{mg}\right.$ ) scraped from the margin of a colony on a PDA plate incubated at $25^{\circ} \mathrm{C} \pm 2{ }^{\circ} \mathrm{C}$ for $7-10$ days. Biospin Fungus Genomic DNA Extraction Kit-BSC14S1 (BioFlux, P.R. China) was used to extract genomic DNA from the mycelium following the manufacturer's protocol. The ITS regions were amplified and sequenced with the primers ITS5/ITS4 (White et al. 1990).

The amplification PCR reactions were performed in a total volume of $25 \mu \mathrm{l}$. PCR mixtures contained TaKaRa Ex-Taq DNA polymerase $0.3 \mu \mathrm{l}, 12.5 \mu \mathrm{l}$ of $2 \times$ PCR buffer with $2.5 \mu \mathrm{l}$ of dNTPs, $1 \mu \mathrm{l}$ of each primer, $9.2 \mu \mathrm{l}$ of double-distilled water and 100-500 ng of DNA template. PCR reactions were run on a BIORAD 1000 Thermal Cycler (Applied Biosystems, Foster City, CA, U.S.A.) under the following conditions. Initial denaturation of 5 minutes at $95{ }^{\circ} \mathrm{C}$, followed by 35 cycles of 30 seconds at $94{ }^{\circ} \mathrm{C}, 45$ seconds annealing at $58{ }^{\circ} \mathrm{C}, 1$ minute at $72{ }^{\circ} \mathrm{C}$, and a final extension of 10 minutes at $72{ }^{\circ} \mathrm{C}$. Positive amplicons were visualised on $1 \%$ agarose gel under UV light using a Gel Doc $^{\mathrm{TM}} \mathrm{XR}+$ Molecular Imager (BIO-RAD, USA). Sequencing of the positive amplicons was carried on a Sun-biotech Company Sequencer (Beijing, China).

\section{Phylogenetic analysis}

Consensus sequences were generated using Geneious ${ }^{\circledR}$ R7 (Biomatters Ltd., New Zealand) and BioEdit (Hall 1999) to ensure sequence integrity. Representative sequences were individually blasted using the MegaBLAST search of NCBIs GenBank nucleotide database (www http://blast.ncbi.nlm.nih.gov/) to retrieve similar taxa for further analyses. The maximum identity with maximum score taxa from the blast searches were selected, and available type strains were included for building the phylogenetic trees. Two different datasets were analysed in this study. First, 104 taxa with Rhizopus oryzae CBS 112.07 as the outgroup taxon were used in the phylogenetic analysis for most of the endophytic isolates recovered. Second, 26 Pseudopithomyces taxa were analysed with Deniquelata barringtoniae as an outgroup taxon to determine species relationships of our putative Pseudopithomyces endophytic isolate. Datasets of ITS regions were aligned online using the MAFFT version 7.221 server. Phylogenetic trees were inferred with maximum likelihood (ML) and Bayesian inference (BI). Maximum likelihood (ML) analysis was calculated online using The CIPRES Science Gateway v. 3.3 (http://www.phylo.org/portal2/, Miller et al. 2010). Bayesian inference was conducted using the Markov Chain Monte Carlo (MCMC) method with MrBayes v. 3.2.2 (Ronquist et al. 2011). The methodologies of these two analyses were performed as described in Doilom et al. (2017). In Bayesian inference, the GTR+I+G was selected as the best-fit nucleotide substitution models under the Akaike information criterion (AIC) for overview phylogeny of the ITS sequence data. Five million generations were selected with a sampling frequency every 100 generations. Phylogenetic trees were visualized using Treeview (Page 1996) and formatted using PowerPoint 2010 (Microsoft Corporation, WA, USA). Sequence data in this study are deposited in GenBank. Accession numbers for each strain are provided in Fig. 3.

\section{Results and Discussion}

\section{Cultural characteristics}

Based on cultural characteristics such as colony shape, colour of hyphae and surface, 154 isolates were grouped into 20 morphotypes. Of these, nine morphotypes sporulated on PDA and they were identified to seven genera viz. Colletotrichum, Diaporthe, Hypoxylon, Neopestalotiopsis, Neodevriesia, Pestalotiopsis and Phyllosticta. The remaining eleven groups were mycelia sterilia on PDA. Different endophytic taxa were selected to be potentially identified to assess our current taxonomic concept based on morphotypes. Growth rate and colony were observed and noted (Table 1, Figs 1,2). These characters are provided as they may be useful for primary identification of endophytic fungi from mangroves and/or other host plants, at least for certain taxonomic groups. However, the colour of mycelium, and growth rates, can vary under different conditions such as 
media, light and temperature. Moreover, grouping of taxa into morphotypes does not reflect species phylogeny as morphotypes are not real taxonomic units (Guo et al. 2003). Surprisingly, some isolates having different cultural characters were found to belong to the same genus (Figs 2a, 2b). Two replicates of the same morphotype showed slightly different cultural characteristics (Figs 2g, 2h).

\section{Phylogenetic analysis}

The blast search results of ITS sequence data are shown in Table 2. The ITS alignments length including gaps comprised 901 and 708 characters for the two datasets investigated (Figs. 3, 4 , respectively). The RAxML analysis resulted in a best scoring likelihood tree selected with a final value for the ITS dataset $=-11994.67091$ (Fig. 3), and -1963.727247 (Fig. 4). The likelihood of the final tree was evaluated and optimized under GAMMA model parameters, with 694 distinct alignment patterns and 38.29\% of completely undetermined characters and gaps (Fig. 3), and 167 distinct alignment patterns and $21.66 \%$ undetermined characters or gaps (Fig. 4). The ITS phylogeny resulted in the detection of 20 taxonomic units residing in 15 known genera (Allophoma, Colletotrichum, Diaporthe, Hortaea, Hypoxylon, Pestalotiopsis, Phanerochaete, Phyllosticta, Pseudopithomyces, Preussia, Neodevriesia, Neopestalotiopsis, Nemania, Rigidoporus, Schizophyllum) and one unidentified ascomycete genus from 30 representative strains out of the 154 isolates (Fig. 3). Thirteen of the genera belong to Ascomycota, while three genera, Phanerochaete, Rigidoporus and Schizophyllum are basidiomycetes. Basidiomycetous fungi such as Polyporales and Rigidoporus have also been found as endophytes in leaves of coniferous trees and Paphiopedilum villosum (Yoo \& Eom 2012, Khamchatra et al. 2016). Details of representative strains of the determined endophytic fungal genera on $R$. apiculata are listed (Table 3). The results of Blast search and ITS phylogeny of these 16 genera as well as additional data and genes are discussed below.

Allophoma - MFLUCC 17-0003 had 100\% matches with many isolates in the MegaBLAST search of NCBIs GenBank nucleotide database. The maximum score was 981, which is similar to e.g. Stagonosporopsis cucurbitacearum E-271 (Table 2). Our ITS based phylogeny does not clearly separate Allophoma from Stagonosporopsis (Fig 3: K). Strain MFLUCC 17-0003 is assigned to Allophoma as the ITS sequence was most similar to this genus. However, S. cucurbitacearum E271 has not been formally published. A combined multi-locus phylogenetic analysis based on ITS, large subunit rDNA (LSU), second largest subunit of RNA polymerase II (RPB2) and $\beta$-tubulin (Tub2), and morphological studies are needed for a better generic delimitation for these closely related genera as has been the case for the Didymellaceae (Chen et al. 2015, 2017, Hyde et al. 2016).

Colletotrichum - Three representative isolates (MFLUCC 17-1943, MFLUCC 17-1944, MFLUCC 17-0004) were identified as Colletotrichum based on morphological and cultural characteristics. ITS sequence data of MFLUCC 17-1943 and MFLUCC 17-1944 were identical, but differed from MFLUCC 17-0004. Based on a MegaBLAST search, the ITS of MFLUCC 17-1943 matched $100 \%$ with many isolates of Colletotrichum and fungal endophytes, but had max score (1074) with C. gloeosporioides AAP-018 and Fungal sp. SF3 (Table 2). Isolate MFLUCC 17-0004 also shared $99 \%$ with many Colletotrichum species, but had a 1088 max score with C. brevisporum PC-1 (Table 2). However, it is known that many species of Colletotrichum cannot be distinguished reliably using ITS (Hyde et al. 2009, Weir et al. 2012), and hence the three representative isolates are named as Colletotrichum spp. Multi-locus gene regions would help determine the current species. Cai et al. (2009) provided detailed protocols for studying Colletotrichum species. Multilocus phylogenetic analyses have typically been used to resolve Colletotrichum species (e.g. Talhinhas et al. 2002, Weir et al. 2012, Damm et al. 2013, Tao et al. 2013). Recommended genetic markers were suggested (Hyde et al. 2014). Genes and combination of genes that can be used for identification of the Colletotrichum species complexes were recommended (Cannon et al. 2012, Hyde et al. 2014) and have been summarized by Jayawardena et al. (2016). For example, a combined of ITS, glyceraldehyde-3-phosphate dehydrogenase (GAPDH), chitin synthase 1 
Table 1 Cultural characteristics of the 20 morphotypes from Rhizophora apiculata on potato dextrose agar (PDA) at $25^{\circ} \mathrm{C}$ in the dark.

\begin{tabular}{|c|c|c|c|c|c|c|c|c|c|}
\hline \multirow[t]{2}{*}{ Morphotype } & \multirow{2}{*}{$\begin{array}{l}\text { Representative } \\
\text { strain }\end{array}$} & \multirow{2}{*}{$\begin{array}{c}\text { Size }(\mathbf{m m}) \\
\text { of } \\
\text { colony after } \\
7 \text { days } \\
\end{array}$} & \multicolumn{2}{|c|}{ Colour ${ }^{\mathrm{a}, \mathrm{b}}$} & \multirow{2}{*}{$\begin{array}{l}\text { Form } \\
\text { Shape }\end{array}$} & \multirow[t]{2}{*}{ Elevation } & \multirow[t]{2}{*}{ Margin } & \multirow[t]{2}{*}{ Density } & \multirow[t]{2}{*}{ Figure } \\
\hline & & & Above & Below & & & & & \\
\hline 1 & MFLUCC17-0025 & $27-35$ & $\begin{array}{l}\text { Orange white } \\
(6 \mathrm{~A} 2) \text { mix with } \\
\text { white (6A1) }\end{array}$ & $\begin{array}{l}\text { Light brown } \\
(6 \mathrm{D} 6)^{\mathrm{a}}, \text { Pale } \\
\text { orange }(5 \mathrm{~A} 3)^{\mathrm{b}}\end{array}$ & Irregular & $\begin{array}{l}\text { Raised to lower } \\
\text { convex }\end{array}$ & Erose or dentate & Spare & $1 \mathrm{a}$ \\
\hline 2 & MFLUCC 17-1941 & $60-65$ & $\begin{array}{l}\text { White }(5 \mathrm{~A} 1)^{\mathrm{a}} \text {, } \\
\text { light orange } \\
(5 \mathrm{~A} 4)^{\mathrm{b}}\end{array}$ & $\begin{array}{l}\text { Orange white } \\
(5 \mathrm{~A} 2)^{\mathrm{a}} \text {, light } \\
\text { orange } \\
(5 \mathrm{~A} 5)^{\mathrm{b}}\end{array}$ & Irregular & $\begin{array}{l}\text { Convex with papillate } \\
\text { surface }\end{array}$ & Undulate & Spare & $1 b$ \\
\hline 3 & MFLUCC 17-0005 & $14-20$ & $\begin{array}{l}\text { Brownish grey } \\
\text { (7D2) mix with } \\
\text { white (7D1) }\end{array}$ & $\begin{array}{l}\text { Black mix with } \\
\text { orange white } \\
(6 \mathrm{~A} 2)\end{array}$ & Irregular & Flat & Erose or dentate & Spare & $1 \mathrm{c}$ \\
\hline 4 & MFLUCC 17-0020 & $37-45$ & $\begin{array}{l}\text { Brown (7E5) } \\
\text { mix with white } \\
\text { (7A1) }\end{array}$ & $\begin{array}{l}\text { Light brown } \\
\text { (7D6) mix with } \\
\text { white (7A1) }\end{array}$ & $\begin{array}{l}\text { Irregular, } \\
\text { punctiform }\end{array}$ & Raised & Undulate & Spare & $1 d$ \\
\hline 5 & MFLUCC 17-1945 & $40-50$ & $\begin{array}{l}\text { Brownish grey } \\
\text { (6F2), brownish } \\
\text { orange (6C4), } \\
\text { alternate } \\
\text { white (6A1) }\end{array}$ & $\begin{array}{l}\text { Brownish grey } \\
(6 \mathrm{~F} 2), \text { white } \\
(6 \mathrm{~A} 1)\end{array}$ & $\begin{array}{l}\text { Irregular to } \\
\text { circular }\end{array}$ & $\begin{array}{l}\text { Raised to convex } \\
\text { with papillate surface }\end{array}$ & Undulate & Medium & $1 \mathrm{e}$ \\
\hline 6 & MFLUCC 17-0004 & $52-60$ & $\begin{array}{l}\text { Greyish brown } \\
\text { (6F3) to (6E3) } \\
\text { alternate white } \\
(6 \mathrm{~A} 1)\end{array}$ & $\begin{array}{l}\text { Greyish brown } \\
\text { (7F3), white } \\
\text { (7D1) and } \\
\text { greyish brown } \\
\text { (7D3) }\end{array}$ & Circular & Flat or effuse to raise & Entire edge & Dense & $1 \mathrm{f}$ \\
\hline 7 & MFLUCC 17-1943 & $50-60$ & $\begin{array}{l}\text { Brownish grey } \\
(7 \mathrm{C} 2)^{\mathrm{a}}, \text { white } \\
(7 \mathrm{~A} 1)^{\mathrm{b}}\end{array}$ & $\begin{array}{l}\text { Brownish grey } \\
(7 D 2)^{a} \text {, white } \\
(7 A 1)^{b}\end{array}$ & Circular & $\begin{array}{l}\text { Raised to convex } \\
\text { with papillate surface }\end{array}$ & Undulate & Medium & $1 \mathrm{~g}$ \\
\hline 8 & MFLUCC 17-0035 & $70-80$ & $\begin{array}{l}\text { Yellowish white } \\
(4 \mathrm{~A} 2)\end{array}$ & $\begin{array}{l}\text { Light yellow } \\
\text { (4A4) }\end{array}$ & Irregular & $\begin{array}{l}\text { Raised convex with } \\
\text { papillate surface }\end{array}$ & $\begin{array}{l}\text { Lobate, with } \\
\text { concentric rings }\end{array}$ & Dense & $1 \mathrm{~h}$ \\
\hline 9 & MFLUCC 17-1942 & $37-45$ & $\begin{array}{l}\text { Pale yellow } \\
(4 \mathrm{~A} 3)^{\mathrm{a}} \text {, white } \\
(4 \mathrm{~A} 1)^{\mathrm{b}}\end{array}$ & $\begin{array}{l}\text { Yellowish } \\
\text { brown }(5 \mathrm{~F} 8)^{\mathrm{a}} \text {, } \\
\text { pale yellow } \\
(4 \mathrm{~A} 3)^{\mathrm{b}}\end{array}$ & Irregular & $\begin{array}{l}\text { Raised to lower } \\
\text { convex }\end{array}$ & $\begin{array}{l}\text { Lobate to } \\
\text { undulate }\end{array}$ & Dense & $1 \mathrm{i}$ \\
\hline 10 & MFLUCC 17-0003 & $22-31$ & $\begin{array}{l}\text { Greyish orange } \\
(5 \mathrm{~B} 4)^{\mathrm{a}} \text {, white } \\
(5 \mathrm{~A} 1)^{\mathrm{b}}\end{array}$ & $\begin{array}{l}\text { Light brown } \\
(6 \mathrm{D} 5)^{\mathrm{a}}, \text { white } \\
(6 \mathrm{~A} 1)^{\mathrm{b}}\end{array}$ & Circular & $\begin{array}{l}\text { Raised to lower } \\
\text { convex }\end{array}$ & Entire edge & Medium & $1 \mathrm{j}$ \\
\hline
\end{tabular}


Table 1 Continued.

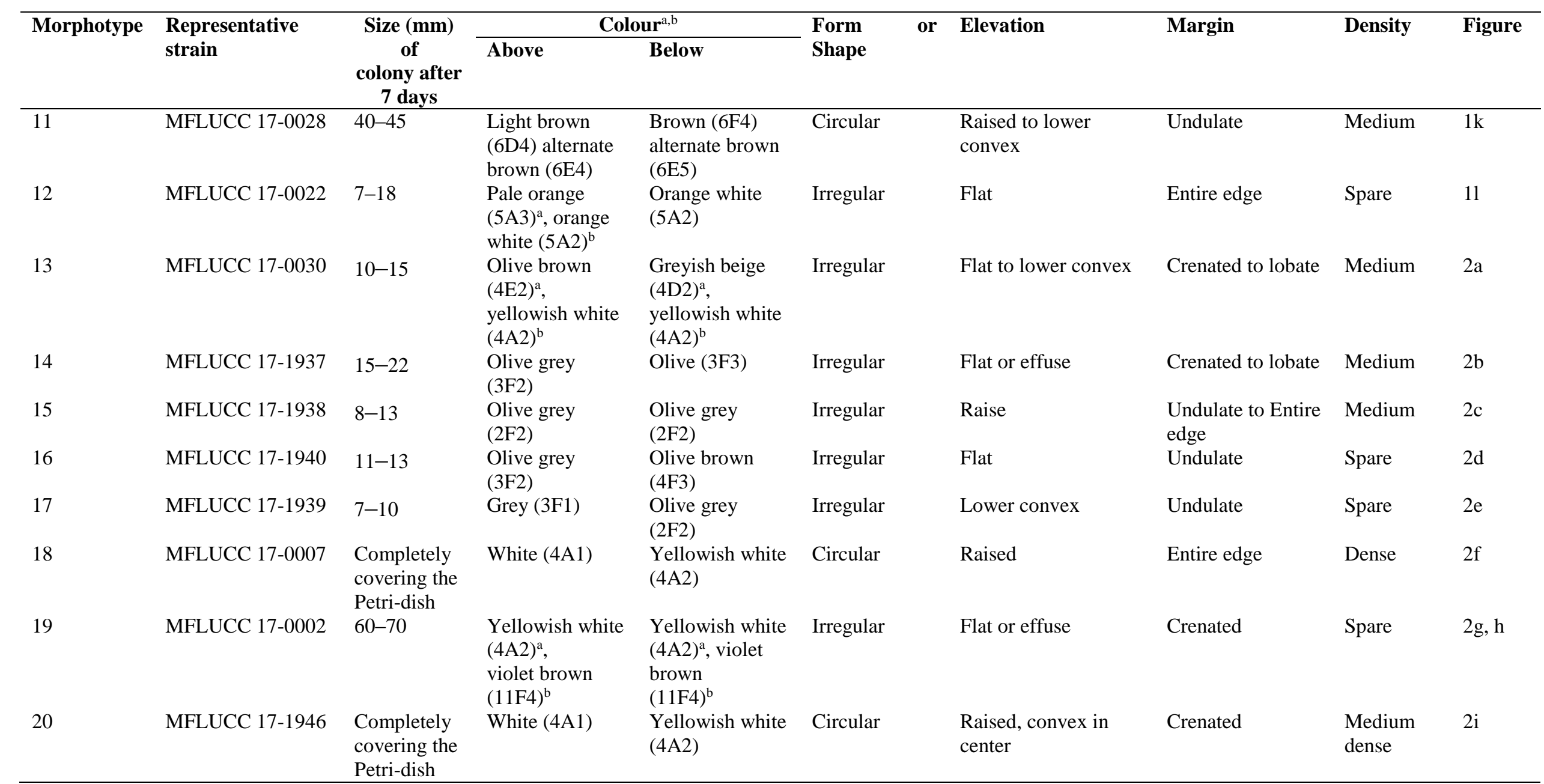

${ }^{\mathrm{a}}$ Center of culture, ${ }^{\mathrm{b}}$ edge of culture. 

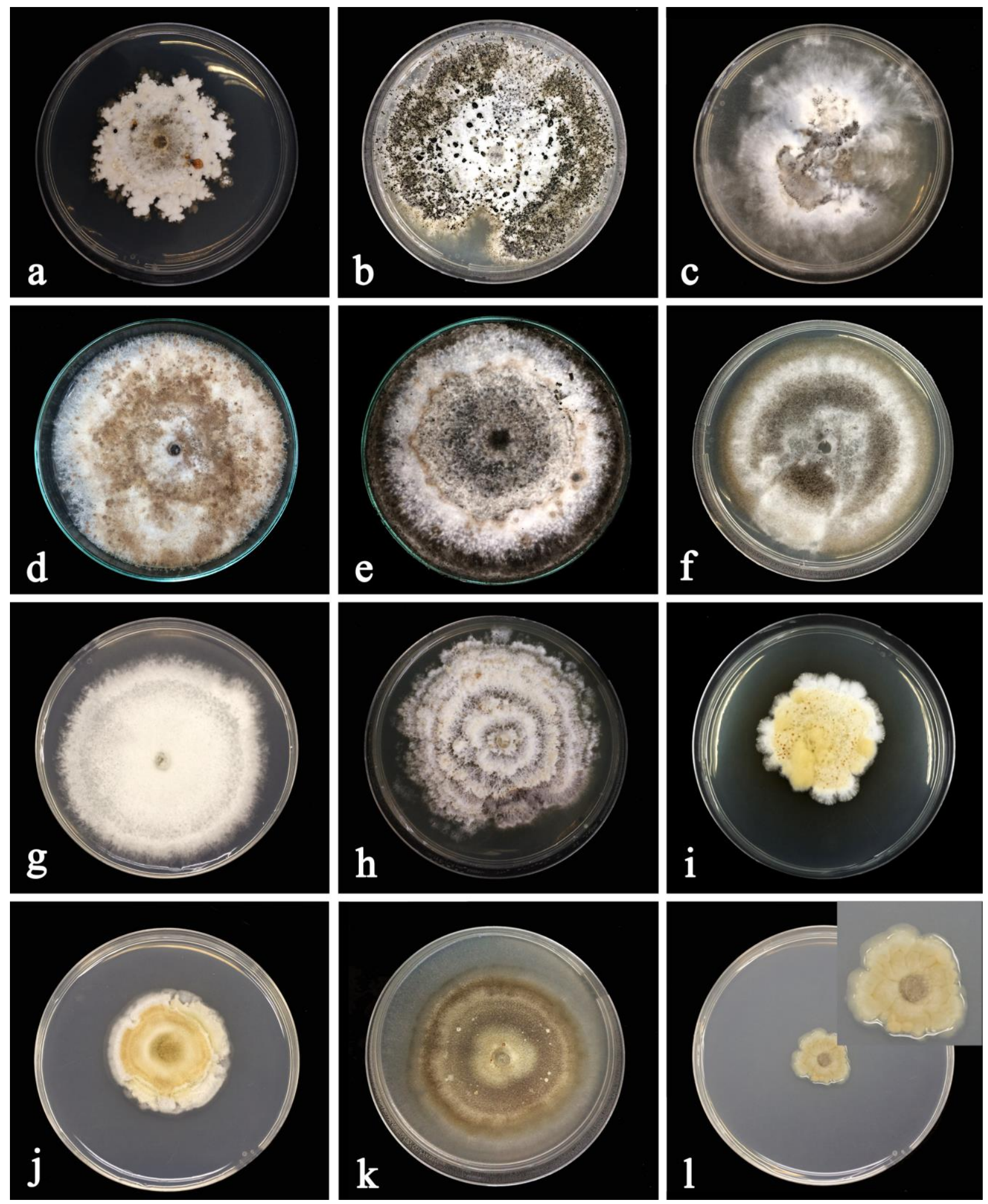

Figure 1 - Colony morphology of fungal endophytes on PDA, at $25{ }^{\circ} \mathrm{C}$ in the dark, isolated from Rhizophora apiculata. a Pestalotiopsis sp. MFLUCC 17-0025 (22 d). b Neopestalotiopsis sp. MFLUCC 17-1941 (30 d). c Nemania sp. MFLUCC 17-0005 (22 d). d Hypoxylon griseobrunneum MFLUCC 17-0020 (22 d). e Hypoxylon sp. MFLUCC 17-1945 (22 d). f Colletotrichum sp. MFLUCC 17-0004 (25 d). g Colletotrichum sp. MFLUCC 17-1943 (14 d). h Diaporthe sp. MFLUCC 17-0035 (5 d). i Diaporthe sp. MFLUCC 17-1942 (14 d). j Allophoma sp. MFLUCC 170003 (14 d). k Pseudopithomyces maydicus MFLUCC 17-0028 (25 d). 1 Preussia sp. MFLUCC17$0022(14 \mathrm{~d})$. 

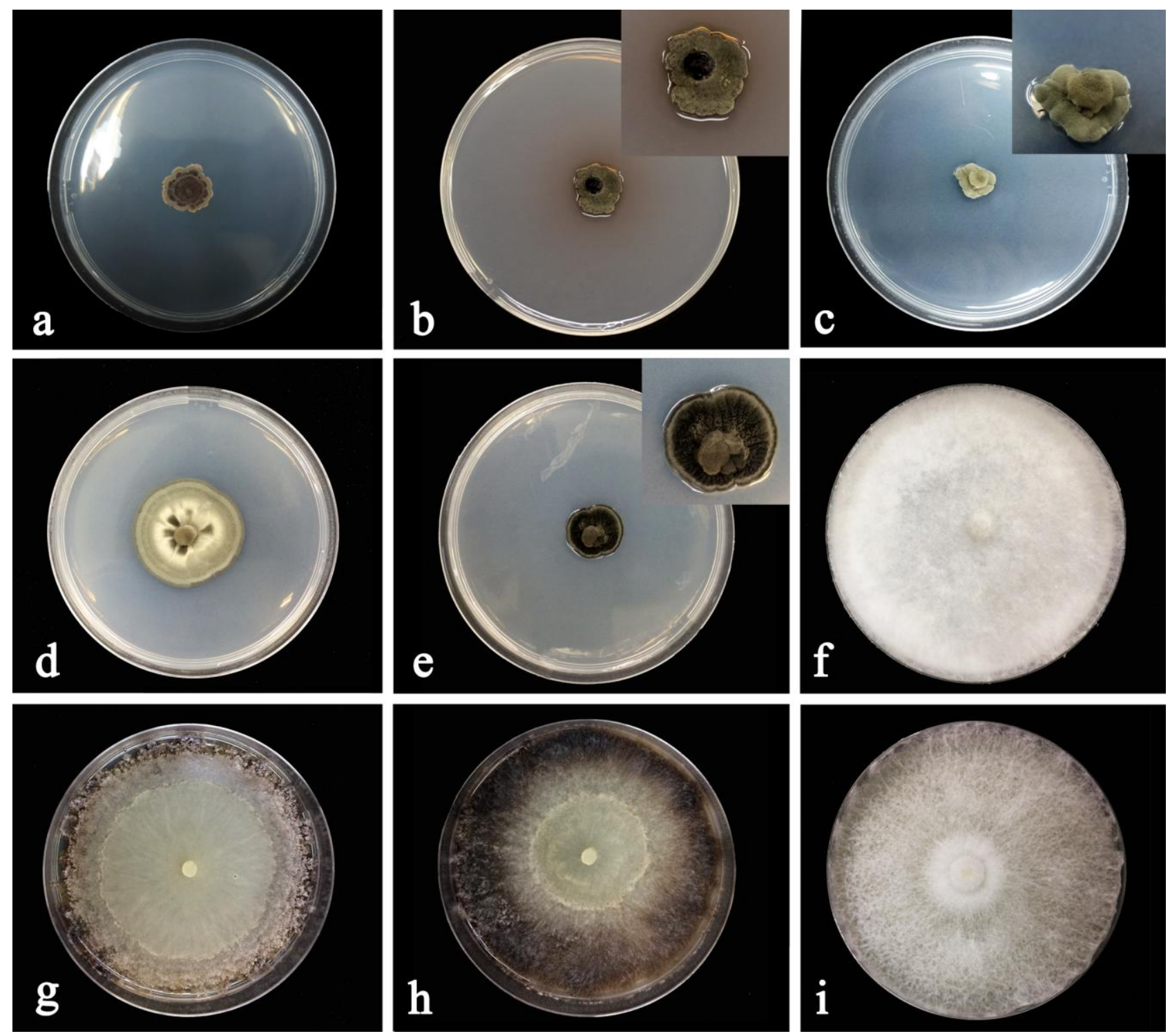

Figure 2 - Colony morphology of fungal endophytes on PDA, at $25{ }^{\circ} \mathrm{C}$ in the dark, isolated from Rhizophora apiculata. a Phyllosticta sp. MFLUCC 17-0030 (14 d). b Phyllosticta sp. MFLUCC 17-1937 (14 d). c Fungal endophyte (unidentified) MFLUCC 17-1938 (14 d). d Hortaea werneckii MFLUCC 17-1940 (30 d). e Neodevriesia sp. MFLUCC 17-1939 (30 d). f Rigidoporus vinctus MFLUCC 17-0007 (30 d). g, h Phanerochaete sp. MFLUCC 17-0002 (25 d). i Schizophyllum sp. MFLUCC 17-1946 (30 d).

(CHS-1), histone H3 (HIS3), actin (ACT) and Tub2 sequences data was used to identify species in the Colletotrichum acutatum species complex (Jayawardena et al. 2016).

Diaporthe - Comparison of nucleotide polymorphism of the ITS sequences data between MFLUCC 17-1942 and MFLUCC 17-0035 showed the major differences over a span of c. 29 polymorphisms. These consist of two deletions, five insertions, 12 transitions and 10 tranversions. Based on the recommendations of Jeewon \& Hyde (2016), we consider these two isolates to be distinct. Blast searches of the ITS, MFLUCC 17-0035 and MFLUCC 17-1942 are provided in Table 2. ITS phylogenetic analysis showed that MFLUCC 17-1942 grouped with Phomopsis sp. MA194 with weak bootstrap support, and next to Diaporthe arengae CBS 114979 (ex-type) with 95\% ML and 0.95 PP (Fig 3: F). These three isolates grouped with Diaporthe arecae CBS 161.64 (ex-isotype) and MFLUCC 17-0035 with 100\% ML and 1.00 PP (Fig. 3, F). However, multiple gene analyses are required to improve the accuracy of species delimitation of these two isolates. Identification of Diaporthe species is not always appropriate using morphological characters, 
because of their plasticity and overlap between different species (Santos \& Phillips 2009). ACT, calmodulin (CAL), HIS3, ITS, translation elongation factor 1-alpha (TEF) and Tub2 should be used in combined analyses with at least 4-5 genes with recommended primers (Udayanga et al. 2012, 2014a, b, Gomes et al. 2013, Hyde et al. 2014, Dissanayake et al. 2017). Santos et al. (2017) suggested that if only four loci can be sequenced these should be TEF, Tub2, CAL and HIS3; if three loci these should be TEF, Tub2 and CAL; if two loci TEF and Tub2; if only one locus TEF as TEF sequence data is the most informative for species separation. ITS sequence data is the least informative to resolve Diaporthe species (Santos et al. 2017). However multi-loci sequence analysis (MLSA) provides more accurate estimation of phylogeny and has less separation errors than single locus analysis, if reasonable loci are used (Gadagkar et al. 2005, Mirarab et al. 2016, Santos et al. 2017).

Hortaea - Based on a MegaBLAST search of NCBIs GenBank nucleotide database, the closest hit using the ITS sequence of MFLUCC 17-1940 matched 100\% and had max score (966) with many isolates such as Hortaea werneckii MCw215 (Table 2). This latter isolate is from a sample of water, collected during the pre-monsoon summer season from mangroves at Santa Cruz, India (Nayak et al. 2012). The ITS phylogeny grouped MFLUCC 17-1940 with H. werneckii MCw215 and CBS 107.67 (ex-neotype) with 100\% ML and 1.00 PP (Fig. 3, H), and is therefore considered to be Hortaea werneckii.

Hypoxylon - ITS sequence data of MFLUCC 17-0020 was identical to MFLUCC 17-0027. The closest hits using a MegaBLAST search of the ITS DNA sequence data of MFLUCC 17-0020 had $100 \%$ similar to several strains, but had a 935 max score to $H$. anthochroum EGJMP20 and Xylariaceae sp. AT4 (unpublished in GenBank 2017) (Table 2). The types and published strains of $H$. griseobrunneum were also included in the ITS phylogeny based on the information from Kuhnert et al. (2014a). Two isolates in this study grouped with H. griseobrunneum agrEK07, STMA06148, CBS 331.73 (ex-type), BCRC 34050 (as H. anthochroum), and H. anthochroum EGJMP20 with 93\% ML and 0.99 PP support (Fig. 3, D). MFLUCC 17-0020 and MFLUCC 170027 are identified as $H$. griseobrunneum based on similarity of ITS sequence data and morphology of the asexual morph being similar to H. griseobrunneum (Kuhnert et al. 2014a). Blast searches of another isolate MFLUCC 17-1945 are provided in Table 2. This isolate grouped sister to H. lechatii MUCL 54609 and CBS 123577 (ex-type) (Kuhnert et al. 2014b), and Xylariaceae sp. D11a4 with 87\% ML and 0.97 PP. Comparison of nucleotide polymorphism of the ITS sequence data differs between our collection MFLUCC 17-1945 and H. lechatii CBS 123577 (ex-type) strain with eight polymorphisms consisting of five transitions, two deletions and one insertion. Thus, MFLUCC 171945 is considered to be Hypoxylon sp., however, it is necessary to compare the Tub2 gene to clarify species level reliably (Kuhnert et al. 2014a, b, Daranagama et al. 2017).

Nemania - MFLUCC 17-0005 was closely related to Nemania diffusa BCC 18754 (Okane et al. 2012) with $100 \%$ sequence similarity and 1003 max score based on a MegaBLAST search (Table 2). Nemania diffusa BCC 18754 has been reported as a xylariaceous endophytic fungus from Pteris decrescens in Thailand (Okane et al. 2012). There are many isolates of $N$. diffusa with ITS sequences data available in GenBank, but the type strain is not sequenced. MFLUCC 17-0005 had high ITS sequence similarity to $N$. diffusa BCC 18754. However, $N$. diffusa BCC 18754 (Okane et al. 2012) showed multiple nucleotide differences from other $N$. diffusa isolates GZ AT-F006 and FR AT-113 (Tang et al. 2007, 2009). MFLUCC 17-0005 is named as Nemania sp. (Fig. 3, C). The isolate should be compared with ex-type cultures for resolving the species name. An epitype for this species should be designated.

Neodevriesia - The ITS of MFLUCC 17-1939 was 99\% similar to Neodevriesia pakbia CBS 139914 (ex-type) (Table 2). This isolate grouped close to, but was distinct from N. pakbia CBS 139914 (ex-type) with 100\% ML and 1.00 PP. MFLUCC 17-1939 is determined to be Neodevriesia sp. (Fig. 3, I). LSU, TEF and Tub2 should be used for further species identification coupled with morphological characterization (Crous et al. 2014).

Neopestalotiopsis - Blast searches of the ITS for isolate MFLUCC 17-1941 is provided in Table 2. The ITS phylogeny suggests it is closely related to Neopestalotiopsis aotearoa CBS 
367.54 (ex-type), N. piceana CBS 394.48 (ex-type), $N$. eucalypticola CBS 264.37 (ex-type), and Pestalotiopsis sp. LH162 (from blast search) with 90\% ML and 1.00 PP (Fig. 3, A), Morphological examination of characters also pointed to the genus Neopestalotiopsis and hence we refer isolate MFLUCC 17-1941 to Neopestalotiopsis sp. However, we refrain from assigning a species name because of morphological plasticity among those species (Jeewon et al. 2002, 2003, Maharachchikumbura et al. 2014). Analysis of combined sequence data of ITS, Tub2 and TEF gene regions is necessary to delimit the species according to Maharachchikumbura et al. $(2014,2016)$.

Pestalotiopsis - ITS sequence data of MFLUCC 17-0016, MFLUCC 17-0018, MFLUCC 170019, MFLUCC 17-0024, MFLUCC 17-0025, MFLUCC 17-0026 and MFLUCC 17-1941 were aligned together in MAFFT. All of these isolates shared identical sequences, except MFLUCC 171941. Isolate MFLUCC 17-0019 was selected as the representative strain of this group and blasted using the GenBank BLAST option. The ITS of MFLUCC 17-0019 had 100\% similarity to several strains, and one of these was Pestalotiopsis sp. SC5A8 with 1075 max score (Table 2). MFLUCC 17-0016, MFLUCC 17-0018, MFLUCC 17-0019, MFLUCC 17-0024, MFLUCC 17-0025 and MFLUCC 17-0026 are named as Pestalotiopsis sp. as they were similar to Pestalotiopsis sp. based on morphological and cultural characteristics, and ITS phylogeny (Fig. 3, B). Most of the key conidial characters are unstable for species level separation as they vary with host range, generation, culture and other environmental conditions (Jeewon et al. 2003, Hu et al. 2007). Naming of species based on morphological characters should be taken into account rather than host association (Jeewon et al. 2004, Maharachchikumbura et al. 2011). Maharachchikumbura et al. (2012) utilized ten gene regions (ACT, Tub2, CAL, GAPDH, glutamine synthetase (GS), ITS, LSU, largest subunit of RNA polymerase II (RPB1), SSU and TEF) to resolve cryptic Pestalotiopsis species, and showed that ITS, Tub2 and TEF were better markers. The other gene regions were less useful owing to poor success in PCR amplification and/or in their ability to determine species delimitation. TEF appeared to be an ideal candidate and functions well to determine species delimitation due to its better species resolution and PCR success. Tub2 showed fairly good differences among species. Combined ITS, Tub2 and TEF gene regions has given a high number of strongly supported nodes at the terminal clades as compared to single gene analysis (Maharachchikumbura et al. 2012, 2014).

Phanerochaete - ITS of MFLUCC 17-0002 had similarity (97\% identity) with 946 max score to Phanerochaete stereoides He2309 (Table 2). ITS phylogeny of MFLUCC 17-0002 grouped sister to P. stereoides He2309 (Liu \& He 2016) with bootstrap support of ML (96\%) and PP (1.00) (Fig. 3O). Isolate MFLUCC 17-0002 is therefore assigned to Phanerochaete sp. RPB1, RPB2, ITS and LSU were used to revised the taxonomy of Phanerochaete (Polyporales, Basidiomycota) (Floudas \& Hibbett 2015).

Phyllosticta - Isolate MFLUCC 17-0030 had 92\% similarity with many species of Phyllosticta, but showed 845 max score with P. aristolochiicola BRIP 53316a (Table 2). MFLUCC 17-0030 and MFLUCC 17-0031 grouped together with 100\% ML and 1.00 PP, but separated from Guignardia sp. 1-3-5-1-3-1 with weak bootstrap support, and next to P. styracicola CGMCC 3.14985 (ex type) with 70\% ML and weak support of PP (Fig. 3J). Another isolate, MFLUCC 171937 was 99\% similar to many isolates, but had max score (1064) with Fungal sp. isolate 59815 (Table 2). MFLUCC 17-1937 grouped 100\% ML and 1.00 PP with Fungal sp. isolate 59815 and $P$. fallopiae MUCC 0113. There are two species of Phyllosticta from Rhizophora apiculata in this study based on ITS sequence data. However multiple genes are required to clarify species names reliably. Wikee et al. (2013a) compared phylogenies of five genes analysis (ACT, GAPDH, ITS, LSU and TEF) with two genes analysis (ACT and ITS). They indicated that the combined ACT and ITS gene loci is sufficiently robust to distinguish most taxa in Phyllosticta, except those closely related to $P$. capitalensis. Wikee et al. (2013b) used analysis of combined ITS, ACT and TEF gene data to confirm the identity of all isolates of $P$. capitalensis. ITS gene and combined analyses of ITS, TEF, GAPDH and ACT sequence data are recommended for generic level and inter-specific delineation respectively (Hyde et al. 2014). A polyphasic approach including morphological, molecular and proteomic techniques were used to improved species identification and delimitation 
(Wulandari et al. 2009, Glienke et al. 2011, Wicht et al. 2012, Wong et al. 2012, Guarnaccia et al. 2017).

Preussia - The ITS sequences of MFLUCC 17-0022 and MFLUCC 17-0023 were identical. Isolate MFLUCC 17-0023 was selected to blast and it matched 99\% with many isolates, but had max score (983) with Preussia sp. CY218 (Table 2). The ITS phylogeny, grouped MFLUCC 170022 and MFLUCC 17-0023 close to Preussia sp. CY218 with 100\% ML and 0.97 PP, and sister to P. persica CBS 117680 (ex-type) with 100\% ML and 1.00 PP (Fig. 3L). Nucleotide differences comparison of the ITS sequence data between our isolates and P. persica CBS 117680 (ex-type) strain reveal nine polymorphisms. Thus, the two isolates are described herein as Preussia sp. Additional genes and morphological characteristics are needed for more precise species delimitation. Arenal et al. (2007) used morphological characters and combined ITS, LSU and TEF loci to erect and identify new species of Preussia.

Pseudopithomyces - Isolate MFLUCC 17-0028 had the highest similarity (100\%) to many isolates, but had max score (1040) with Pithomyces maydicus UTHSC 06-1549 (da Cunha et al. 2014) However, Pithomyces maydicus (Sacc.) M.B. Ellis was combined as Pseudopithomyces maydicus (Sacc.) J.F. Li, Ariyawansa \& K.D. Hyde by Ariyawansa et al. (2015). The genus Pseudopithomyces comprises P. chartarum (Berk. \& M.A. Curtis) M.B. Ellis, P. maydicus, P. sacchari (Speg.) M.B. Ellis and some unidentified Pithomyces strains, which group together in Didymosphaeriaceae (Ariyawansa et al. 2015). The isolate in this study (MFLUCC 17-0028) grouped with $P$. maydicus UTHSC 06-1549 and UTHSC 06-3954 with high statistical support (Fig. 3, M). Pseudopithomyces species can be separated based on ITS phylogeny in this study (Fig. 4). Isolate MFLUCC 17-0028 is therefore considered as P. maydicus. A combined dataset of ITS, LSU, GAPDH and RPB2 has also been reported to resolve taxonomy of Pseudopithomyces species (Crous et al. 2016).

Rigidoporus - MFLUCC 17-0007 had a high sequence similarity (100\%) identity and 1158 max score with Rigidoporus vinctus FRIM142 (Table 2). ITS phylogeny placed this isolate with $R$. vinctus FRIM142, PAPH04 and N_L7_E6 with 100\% ML and 1.00 PP (Fig. 3N), and it is therefore considered to be Rigidoporus vinctus.

Schizophyllum - ITS sequence data of MFLUCC 17-1946 was selected to blast as it was identical to the ITS sequence of MFLUCC 17-1947. Isolate MFLUCC 17-1946 showed 99\% sequence similarity and 1146 max score with Schizophyllum commune isolate UZ1552_14 (Table 2). Other published isolates and reference strains of Schizophyllum were also included in the ITS phylogeny (Siqueira et al. 2016). The isolates in this study could not be well separated from $S$. commune and S. radiatum (Fig. 3P). Therefore, the two isolates are determined to be Schizophyllum sp. Siqueira et al. (2016) noted that the phylogenetic analyses of the individual ITS and LSU genes were much conserved and did not discriminate well between the closely related species $S$. commune and $S$. radiatum. The LSU, TEF, and RPB2 markers showed consistency and were used to perform a concatenated study.

Unidentified - MFLUCC 17-1938 showed a sequence similarity (99\%) and max score (983) with Mycosphaerellaceae sp. MA12 (Table 2). Isolate MA12 is an endophyte on a mangrove plant in the South of Thailand, and Buatong (2010) placed it in Mycosphaerellaceae and reported that the isolate displayed strong antifungal activity against Cryptococcus neoformans ATCC90112. ITS phylogeny groups our isolate (MFLUCC 17-1938) with Mycosphaerellaceae sp. MA12 with 100\% ML and 1.00 PP (Fig. 3G). MFLUCC 17-1938 and Mycosphaerellaceae sp. MA12 are nested in between the genera Devriesia and Hortaea which are classified in the Teratosphaeriaceae (Fig. 3G). We could not observe morphological details on culture of MFLUCC 17-1938 as it did not produce spores. Thus, isolate MFLUCC 17-1938 remains an unidentified taxon.

The use of highest nucleotide similarity in MegaBLAST searches of NCBIs GenBank nucleotide database is a preliminary step towards determining fungal endophyte species. The top score match may not necessarily indicate the same species (Kang et al. 2010). It is difficult to make conclusions for isolates within or related to species complexes based on MegaBLAST searches and phylogenetic analysis of ITS sequences data. However, the ITS region is still useful in some cases 
for reconstruction of interspecific relationships (Cai et al. 2009). Although ITS has been formally proposed as the primary barcoding marker for fungi by the Consortium for the Barcode of Life, there is the possibility that supplementary barcodes may be developed for particularly narrowly circumscribed taxonomic groups (Schoch et al. 2012). It is better to use multigene analysis to accurately identify species of fungal endophytes (Guo et al. 2001, Huang et al. 2009, Ko et al. 2011, Sun et al. 2011). Moreover, most of the sequences named in GenBank are erroneously named, such as Colletotrichum and Curvularia lunata (Cai et al. 2009, 2011, da Cunha et al. 2013). A comparison of sequence data from fungal endophytes with ex-type cultures of named species must be considered (Dayarathne et al. 2016). This will prevent misidentification of endophytes isolated from various hosts and localities (Ko et al. 2011). Correct identification of fungi is important for understanding the biology, ecology, evolutionary relationships, for controlling plant diseases, and useful for future application in biotechnology (Santos \& Phillips 2009, Ko et al. 2011, Udayanga et al. 2011, Hyde et al. 2014).

\section{Comparison between culture-dependent and culture-independent techniques}

ITS is the targeted region in culture-dependent or NGS analysis. In this study, we identified the fungal endophytes based on ITS sequence data using the culture-dependent approach, which is different from culture-independent methods (e.g. study using NGS that reads into operational taxonomic units (OTUs)). The identification of bacteria and fungi by culture-dependent methods has resulted in lower numbers of microorganisms than culture-independent methods (Carraro et al. 2011, Stefani et al. 2015). This is because culture conditions used (aeration, nutritional, temperature, etc.) can affect growth of organisms. Artificial medium usually allows growth of only a small fraction of the organisms (Carraro et al. 2011). Fast-growing species suppress growth of others, thus slow-growing organisms are out-competed (Nocker et al. 2007). Culture-independent methods can also reveal the community of unculturable organisms. Nevertheless, culture-dependent methods have higher taxonomical accuracy (discriminative power), and ease of performance and interpretation when compared to culture-independent methods ((denaturing gradient gel electrophoresis (DGGE) and 454 Pyrosequencing) (Vaz-Moreira et al. 2011). Moreover, culturing is essential for future applications in agricultural, industrial, food and medicine.

New high-throughput methods, in the culture-independent approach, are a useful strategy to estimate diversity of the mycobiome from any substrate. However, methodological biases, limitations of the markers and bioinformatic analysis, may lead to misleading conclusions (Lindahl et al. 2013, Vaz et al. 2017). Operational taxonomic units are based on sequences with $\geq 97 \%$ similarity. However, several problems can be seen in this method. If the ITS sequences of two species are $\geq 97 \%$ similar they can be assigned into one OTU instead of two. Another problem is that the same species that has a similarity less than $97 \%$ can be assigned as two different OTUs. This can be observed clearly in species complexes such as Colletotrichum and Diaporthe. Also, in the OUT dataset, species that occur only once are considered as rare OTUs or singletons considering that they may have originated from sequencing errors. In most cases, the fungal identifications from both methods can be consistent. However, inconsistent identifications can occur due to the lower power of taxonomic assignment in the culture-independent (amplicon sequencing) as compared with culture dependent approaches. This will result in identifying the organisms to family, order or class level instead of species level.

\section{Conclusions}

We resolved four endophyte species out of an estimated 20 morphotypes in this study based on ITS sequence data and cultural characteristic as well as support with available morphological study of sporulating species. These were Hortaea werneckii, Hypoxylon griseobrunneum, Pseudopithomyces maydicus and Rigidoporus vinctus and accuracy depends on the fungal group. These four species are first reports on Rhizophora apiculata. Both Ascomycota and Basidiomycota genera were found from Rhizophora apiculate, with Ascomycota being the most abundant. ITS 
sequence data can be used to identify taxa that have identical nucleotide sequence data to those of ex-types of species. ITS can separate species or indicate new species when having nucleotide

Table 2 Closest match for endophytes following MegaBLAST search of NCBI GenBank nucleotide database. Max identity and max score are shown.

\begin{tabular}{|c|c|c|c|c|c|}
\hline $\begin{array}{l}\text { Isolate } \\
\text { number in this } \\
\text { study }\end{array}$ & $\begin{array}{l}\text { Nearest match BLAST } \\
\text { search result }\end{array}$ & $\begin{array}{l}\text { Voucher/ } \\
\text { Culture }\end{array}$ & $\begin{array}{l}\text { ITS } \\
\text { GenBank } \\
\text { accession } \\
\text { number }\end{array}$ & $\begin{array}{l}\text { Max } \\
\text { score }\end{array}$ & $\begin{array}{l}\text { Max } \\
\text { identity } \\
(\%)\end{array}$ \\
\hline \multicolumn{6}{|l|}{ Ascomycota } \\
\hline \multirow[t]{3}{*}{ MFLUCC 17-0003 } & $\begin{array}{l}\text { Stagonosporopsis } \\
\text { cucurbitacearum }\end{array}$ & E-271 & KU059901 & 981 & $531 / 531(100 \%)$ \\
\hline & $\begin{array}{l}\text { Stagonosporopsis } \\
\text { cucurbitacearum }\end{array}$ & SE5 & AB714984 & 981 & $531 / 531(100 \%)$ \\
\hline & Didymella bryoniae & MA71 & GU592001 & 981 & $531 / 531(100 \%)$ \\
\hline MFLUCC 17-0004 & $\begin{array}{l}\text { Colletotrichum } \\
\text { brevisporum }\end{array}$ & PC-1 & KX756146 & 1088 & 602/608(99\%) \\
\hline MFLUCC 17-0005 & Nemania diffusa & BCC 18754 & AB625422 & 1003 & $543 / 543(100 \%)$ \\
\hline \multirow[t]{3}{*}{ MFLUCC 17-0019 } & Pestalotiopsis sp. & SC5A8 & KU252287 & 1075 & $582 / 582(100 \%)$ \\
\hline & Pestalotiopsis sp. & SC3A14 & KU252282 & 1075 & $582 / 582(100 \%)$ \\
\hline & Pestalotiopsis sp. & SC3A4 & KU252277 & 1075 & $582 / 582(100 \%)$ \\
\hline \multirow[t]{2}{*}{ MFLUCC 17-0020 } & Hypoxylon anthochroum & EGJMP 20 & KF192825 & 935 & $506 / 506(100 \%)$ \\
\hline & Xylariaceae sp. & AT4 & KX953392 & 935 & $506 / 506(100 \%)$ \\
\hline MFLUCC 17-0023 & Preussia sp. & CY218 & HQ608038 & 983 & $539 / 542(99 \%)$ \\
\hline MFLUCC 17-0028 & Pithomyces maydicus & UTHSC 06-1549 & HG933801 & 1040 & $563 / 563(100 \%)$ \\
\hline MFLUCC 17-0030 & $\begin{array}{l}\text { Phyllosticta } \\
\text { aristolochiicola }\end{array}$ & BRIP 53316a & NR_111791 & 845 & $574 / 627(92 \%)$ \\
\hline MFLUCC 17-0035 & Diaporthe arecae & CBS 161.64 & KC343032 & 1026 & $560 / 562(99 \%)$ \\
\hline MFLUCC 17-1937 & Fungal sp. & 59815 & KP890364 & 1064 & $592 / 600(99 \%)$ \\
\hline MFLUCC 17-1938 & Mycosphaerellaceae sp. & MA 12 & GU591997 & 983 & $542 / 547(99 \%)$ \\
\hline MFLUCC 17-1939 & Neodevriesia pakbiae & $\begin{array}{l}\text { CPC 25044/ } \\
\text { CBS } 139914\end{array}$ & KR476742 & 998 & $557 / 565(99 \%)$ \\
\hline \multirow[t]{7}{*}{ MFLUCC 17-1940 } & Hortaea werneckii & MCw215 & HQ711621 & 966 & $523 / 523(100 \%)$ \\
\hline & Fungal endophyte & 2789 & KR015340 & 966 & $523 / 523(100 \%)$ \\
\hline & Hortaea werneckii & RY 51 & KM014604 & 966 & $523 / 523(100 \%)$ \\
\hline & Hortaea werneckii & JY 54 & KM014589 & 966 & $523 / 523(100 \%)$ \\
\hline & Hortaea werneckii & Hw5 & JN997374 & 966 & $523 / 523(100 \%)$ \\
\hline & Hortaea sp. & F47 & FJ755827 & 966 & $523 / 523(100 \%)$ \\
\hline & Hortaea werneckii & IFM 4988 & AB087199 & 966 & $523 / 523(100 \%)$ \\
\hline \multirow[t]{4}{*}{ MFLUCC 17-1941 } & Pestalotiopsis sp. & LH162 & HQ832816 & 1003 & $547 / 549(99 \%)$ \\
\hline & Pestalotiopsis sp. & MA129 & GQ254681 & 1003 & $547 / 549(99 \%)$ \\
\hline & Pestalotiopsis sp. & MA165 & GU592005 & 1003 & $547 / 549(99 \%)$ \\
\hline & Pestalotiopsis sp. & 14JAES & EF451799 & 1003 & $547 / 549(99 \%)$ \\
\hline MFLUCC 17-1942 & Phomopsis sp. & MA194 & GU592007 & 1029 & $572 / 579(99 \%)$ \\
\hline \multirow[t]{2}{*}{ MFLUCC 17-1943 } & $\begin{array}{l}\text { Colletotrichum } \\
\text { gloeosporioides }\end{array}$ & AAP-018 & KU534983 & 1074 & $581 / 581(100 \%)$ \\
\hline & Fungal sp. & SF3 & MF962538 & 1074 & $581 / 581(100 \%)$ \\
\hline \multirow[t]{2}{*}{ MFLUCC 17-1945 } & Xylariaceae sp. & D11a4 & JQ341090 & 1068 & 604/616(98\%) \\
\hline & Hypoxylon lechatii & MUCL 54609 & KF923407 & 1068 & $606 / 619(98 \%)$ \\
\hline \multicolumn{6}{|l|}{ Basidiomycota } \\
\hline MFLUCC 17-0002 & Phanerochaete stereoides & He2309 & KX212219 & 946 & $547 / 564(97 \%)$ \\
\hline MFLUCC 17-0007 & Rigidoporus vinctus & FRIM 142 & HQ400710 & 1158 & $627 / 627(100 \%)$ \\
\hline MFLUCC 17-1946 & Schizophyllum commune & UZ1552_14 & KP326577 & 1146 & $625 / 627(99 \%)$ \\
\hline
\end{tabular}




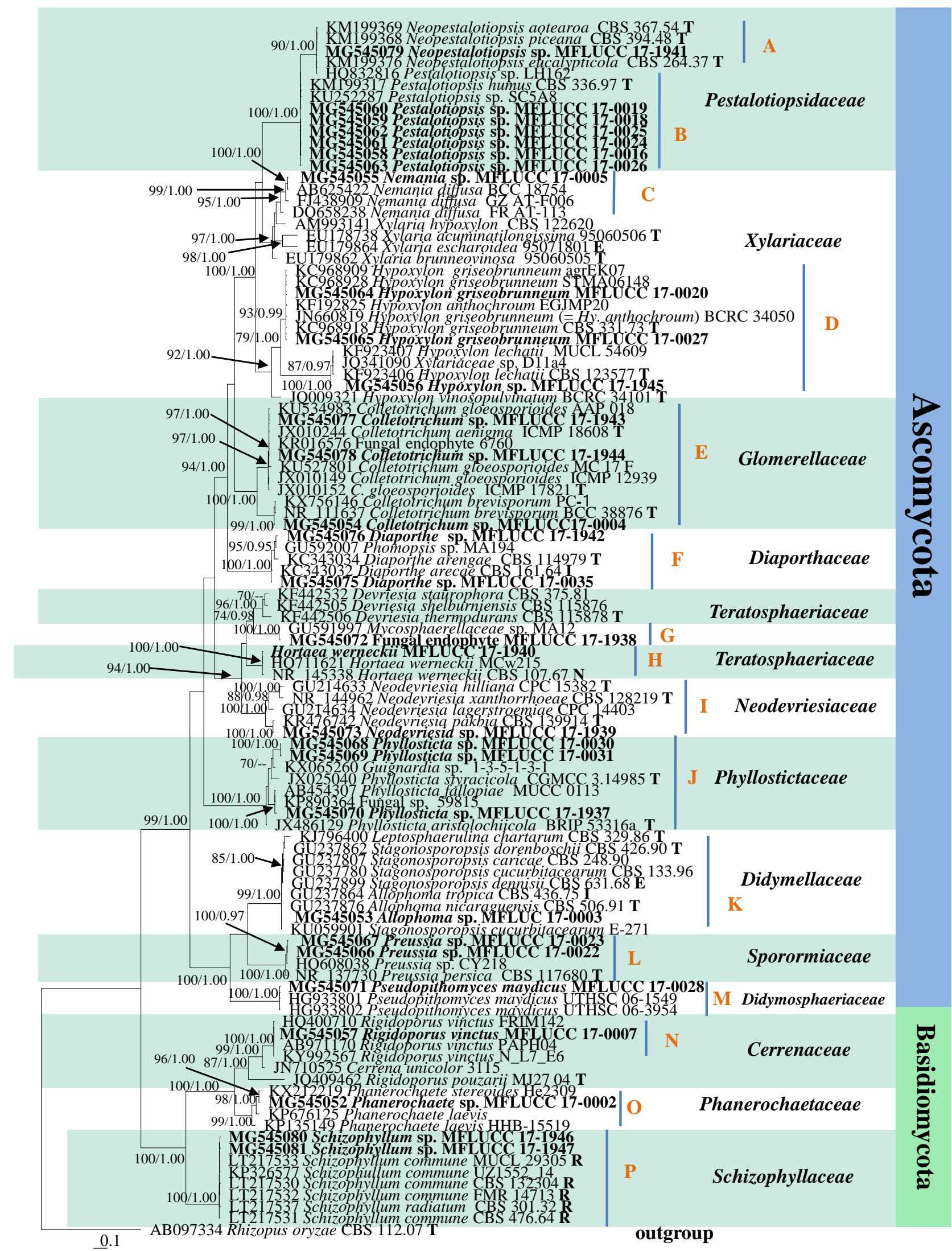

Figure 3 - Phylogram generated from maximum likelihood analysis (RAxML) based on ITS sequence data. The tree is rooted to Rhizopus oryzae CBS 112.07. Maximum likelihood bootstrap values (MLBS) $\geq 70 \%$ and Bayesian posterior probabilities $\geq 0.95$, (MLBS/PP) are given at the nodes. Ex-epitype, ex-isotype, ex-neotype, ex-type and reference strains are marked with E, I, N, T and $\mathrm{R}$, respectively. The new isolates are in bold. 


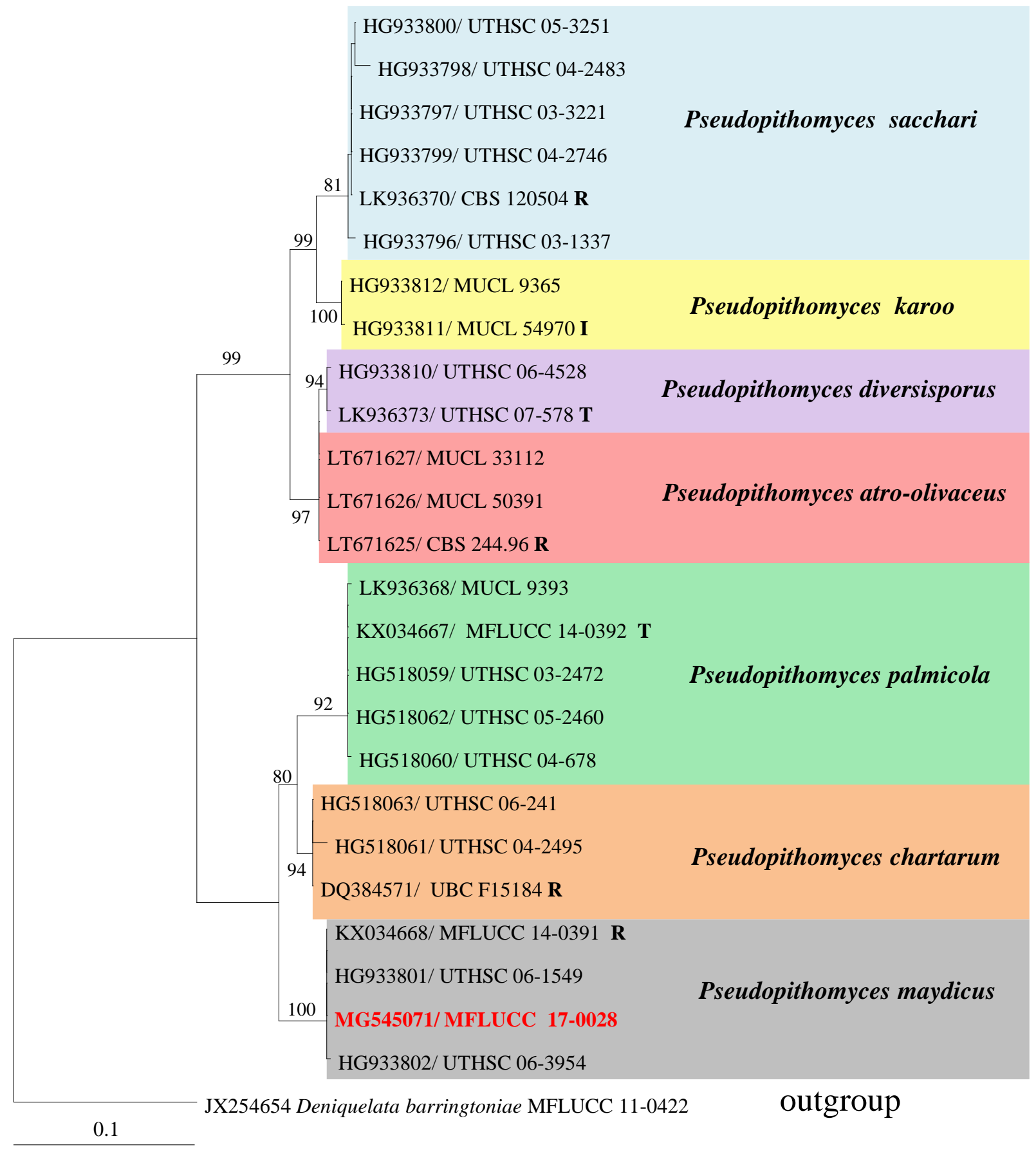

Figure 4 - Phylogram generated from maximum likelihood analysis (RAxML) based on ITS sequence data in Pseudopithomyces species. The tree is rooted to Deniquelata barringtoniae MFLUCC 11-0422. Maximum likelihood bootstrap values (MLBS) $\geq 70 \%$ are given at the nodes. Ex-isotype, ex-type and reference strains are marked with I, T and R, respectively. The new isolate is in red bold.

sequence clearly diverges from previous described species. Individual ITS can clearly discriminate Pseudopithomyces species. ITS sequence data are hardly enough to identify the species boundary for species complex such as Colletotrichum and Diaporthe, in fact for most genera isolated in this study, but can provide an idea for taxonomic groups at least to genus level in most cases. Additional data and analysis, especially from multiple gene loci, are required to identify fungal endophytes. 
Table 3 Details of representative strains of isolated endophytic fungi from Rhizophora apiculata.

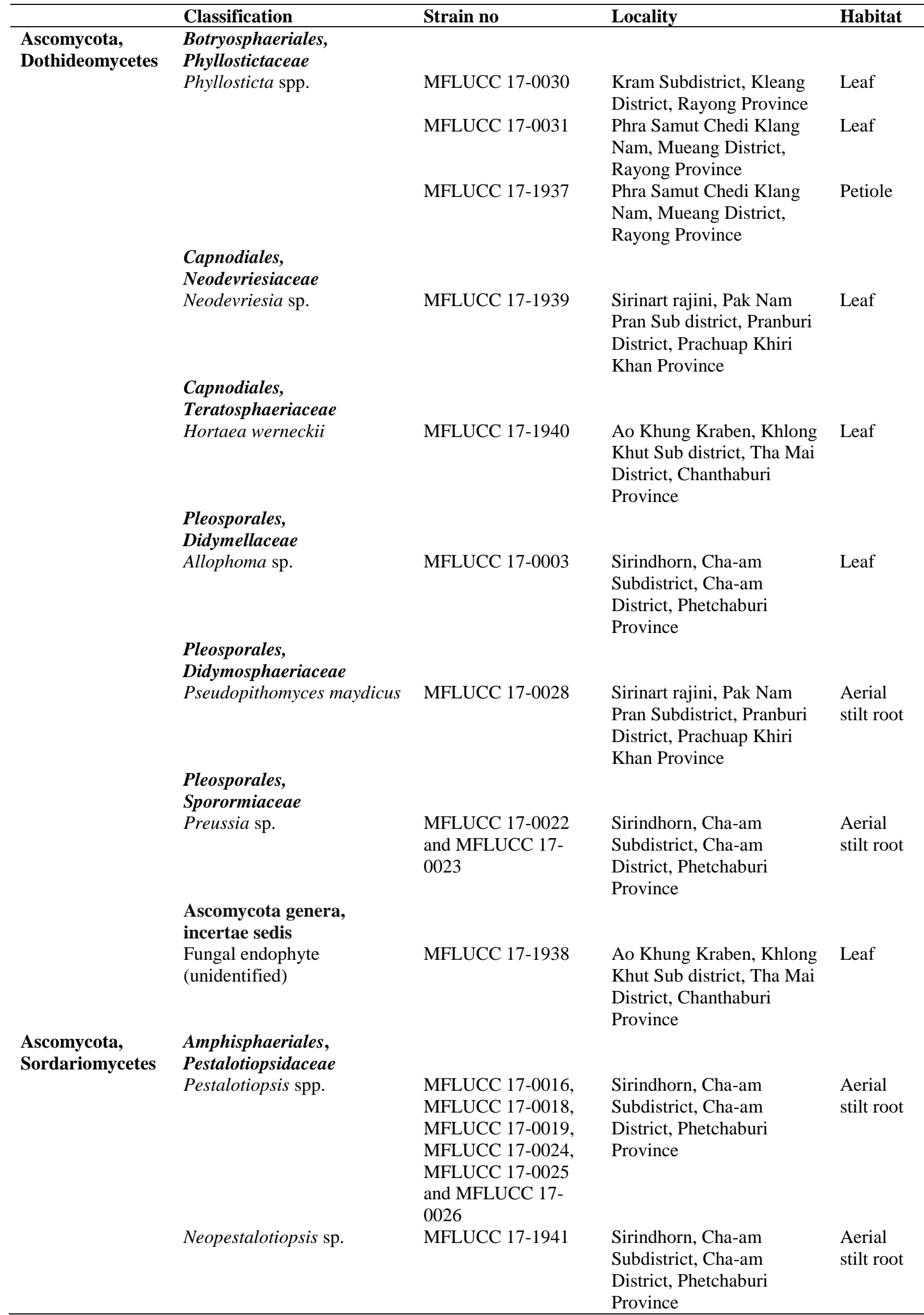


Table 3 Continued.

\begin{tabular}{|c|c|c|c|c|}
\hline & Classification & Strain no & Locality & Habitat \\
\hline \multirow[t]{10}{*}{$\begin{array}{l}\text { Ascomycota, } \\
\text { Sordariomycetes }\end{array}$} & $\begin{array}{l}\text { Diaporthales, } \\
\text { Diaporthaceae }\end{array}$ & & & \\
\hline & Diaporthe sp. & MFLUCC 17-0035 & $\begin{array}{l}\text { Kram Subdistrict, Kleang } \\
\text { District, Rayong Province }\end{array}$ & $\begin{array}{l}\text { Aerial } \\
\text { stilt root }\end{array}$ \\
\hline & Diaporthe sp. & MFLUCC 17-1942 & $\begin{array}{l}\text { Kram Subdistrict, Kleang } \\
\text { District, Rayong Province }\end{array}$ & $\begin{array}{l}\text { Aerial } \\
\text { stilt root }\end{array}$ \\
\hline & $\begin{array}{l}\text { Glomerellales, } \\
\text { Glomerellaceae }\end{array}$ & & & \\
\hline & Colletotrichum sp. & MFLUCC 17-0004 & $\begin{array}{l}\text { Sirindhorn, Cha-am } \\
\text { Subdistrict, Cha-am } \\
\text { District, Phetchaburi } \\
\text { Province }\end{array}$ & Leaf \\
\hline & Colletotrichum sp. & MFLUCC 17-1943 & $\begin{array}{l}\text { Kram Subdistrict, Kleang } \\
\text { District, Rayong Province }\end{array}$ & Leaf \\
\hline & Colletotrichum sp. & MFLUCC 17-1944 & $\begin{array}{l}\text { Sirinart rajini, Pak Nam } \\
\text { Pran Subdistrict, Pranburi } \\
\text { District, Prachuap Khiri } \\
\text { Khan Province }\end{array}$ & Leaf \\
\hline & $\begin{array}{l}\text { Xylariales, Xylariaceae } \\
\text { Hypoxylon griseobrunneum }\end{array}$ & $\begin{array}{l}\text { MFLUCC 17-0020 } \\
\text { and MFLUCC 17- } \\
0027\end{array}$ & $\begin{array}{l}\text { Sirinart rajini, Pak Nam } \\
\text { Pran Subdistrict, Pranburi } \\
\text { District, Prachuap Khiri } \\
\text { Khan Province }\end{array}$ & Leaf \\
\hline & Hypoxylon sp. & MFLUCC 17-1945 & $\begin{array}{l}\text { Sirinart rajini, Pak Nam } \\
\text { Pran Subdistrict, Pranburi } \\
\text { District, Prachuap Khiri } \\
\text { Khan Province }\end{array}$ & Leaf \\
\hline & Nemania sp. & MFLUCC 17-0005 & $\begin{array}{l}\text { Sirindhorn, Cha-am } \\
\text { Subdistrict, Cha-am } \\
\text { District, Phetchaburi } \\
\text { Province }\end{array}$ & Leaf \\
\hline \multirow[t]{4}{*}{$\begin{array}{l}\text { Basidiomycota, } \\
\text { Agaricomycetes }\end{array}$} & $\begin{array}{l}\text { Agaricales, } \\
\text { Schizophyllaceae } \\
\text { Schizophyllum sp. }\end{array}$ & $\begin{array}{l}\text { MFLUCC 17-1946 } \\
\text { and MFLUCC 17- } \\
1947\end{array}$ & $\begin{array}{l}\text { Sirinart rajini, Pak Nam } \\
\text { Pran Subdistrict, Pranburi } \\
\text { District, Prachuap Khiri } \\
\text { Khan Province }\end{array}$ & $\begin{array}{l}\text { Aerial } \\
\text { stilt root }\end{array}$ \\
\hline & $\begin{array}{l}\text { Polyporales, Cerrenaceae } \\
\text { Rigidoporus vinctus }\end{array}$ & MFLUCC 17-0007 & $\begin{array}{l}\text { Sirindhorn, Cha-am } \\
\text { District, Phetchaburi } \\
\text { Province }\end{array}$ & Petiole \\
\hline & $\begin{array}{l}\text { Polyporales, } \\
\text { Phanerochaetaceae }\end{array}$ & & & \\
\hline & Phanerochaete sp. & MFLUCC 17-0002 & $\begin{array}{l}\text { Sirindhorn, Cha-am } \\
\text { District, Phetchaburi } \\
\text { Province }\end{array}$ & Leaf \\
\hline
\end{tabular}

\section{Acknowledgements}

This work was financially supported by Thailand Research Fund (TRF) grant no RSA5980068 entitled "Biodiversity, phylogeny and role of fungal endophytes on above parts of Rhizophora apiculata and Nypa fruticans'”. K.D. Hyde would like to thank National Research Council of Thailand (Mae Fah Luang University) grant no 60201000201 entitled "Diseases of mangrove trees and maintenance of good forestry practice'. K.D. Hyde is adjunct professor at Chiang Mai University. We are appreciative and thankful to staff at Ao Kung Krabaen Bay Nature Center, The Sirindhorn International Environment Park and Sirinart Rajini Ecosystem Learning Center for giving us the knowledge, and granting us permission to study and collect mangrove 
specimens. Mingkwan Doilom is grateful to Dr. Joanne E. Taylor (Royal Botanic Garden Edinburgh, Scotland, UK) and Assoc. Prof. Dr. JianKui Liu (Guizhou Institute of Biotechnology, Guizhou Academy of Agricultural Sciences, Guiyang, Guizhou, China) for kind suggestions on the manuscript.

\section{References}

Aly AH, Debbab A, Kjer J, Proksch P. 2010 - Fungal endophytes from higher plants: a prolific source of phytochemicals and other bioactive natural products. Fungal Diversity 41, 1-16.

Arenal F, Platas G, Peláez F. 2007 - A new endophytic species of Preussia (Sporormiaceae) inferred from morphological observations and molecular phylogenetic analysis. Fungal Diversity $25,1-17$.

Ariyawansa HA, Hyde KD, Jayasiri SC, Buyck B et al. 2015 - Fungal diversity notes 111-252: taxonomic and phylogenetic contributions to fungal taxa. Fungal Diversity 75, 27-274.

Arnold A. 2002 - Neotropical fungal endophytes: diversity and ecology. University of Arizona, Tucson, Ph.D. thesis.

Bharathidasan R, Panneerselvam A. 2011 - Isolation and identification of endophytic fungi from Avicennia marina in Ramanathapuram District, Karankadu, Tamilnadu, India. European Journal of Experimental Biology 1, 31-36.

Bills GF. 1996 - Isolation and analysis of endophytic fungal communities from woody plants. In Redlin SC, Carris LM, St Paul MN (eds.). Endophytic fungi in grasses and woody plants, APS Press, USA, 31-65.

Buatong J. 2010 - Endophytic fungi producing antimicrobial substances from mangrove plants in the south of Thailand. Prince of Songkla University, Thailand, MSc thesis.

Cai L, Hyde KD, Taylor PWJ, Weir B et al. 2009 - A polyphasic approach for studying Colletotrichum. Fungal Diversity 39, 183-204.

Cai L, Udayanga D, Manamgoda DS, Maharachchikumbura SSN et al. 2011 - The need to carry out re-inventory of plant pathogenic fungi. Tropical Plant Pathology 36, 205-213.

Cannon PF, Damm U, Johnston PR, Weir BS. 2012 - Colletotrichum-current status and future directions. Studies in Mycology 73, 181-213.

Carraro L, Maifreni M, Bartolomeoli I, Martino ME et al. 2011 - Comparison of culture-dependent and-independent methods for bacterial community monitoring during Montasio cheese manufacturing. Research in Microbiology 162, 231-239.

Carroll GC. 1986 - The biology of endophytism in plants with particular reference to woody perennials. In Fokkema NJ, Van den Heuve J (eds.). Microbiology of the Phyllosphere. Cambridge, Cambridge University Press, 205-222.

Chaeprasert S, Piapukiew J, Whalley AJ, Sihanonth P. 2010 - Endophytic fungi from mangrove plant species of Thailand: their antimicrobial and anticancer potentials. Botanica Marina 53, 555-564.

Chaowalit P. 2009 - Screening of endophytic fungi from mangrove plants which produce lipase, cellulase, amylase or protease enzymes. Prince of Songkla University, Thailand, MSc thesis.

Chen Q, Jiang JR, Zhang GZ, Cai L, Crous PW. 2015 - Resolving the Phoma enigma. Studies in Mycology 82, 137-217.

Chen Q, Hou LW, Duan WJ, Crous PW, Cai L. 2017 - Didymellaceae revisited. Studies in Mycology 87, 105-159.

Crous PW, Shivas RG, Quaedvlieg W, van der Bank M et al. 2014 - Fungal Planet description sheets: 214-280. Persoonia 32, 184-306.

Crous PW, Wingfield MJ, Burgess TI, Hardy GESJ et al. 2016 - Fungal Planet description sheets: 469-557. Persoonia 37, 218-403.

da Cunha KC, Sutton DA, Fothergill AW, Gené J et al. 2013 - In vitro antifungal susceptibility and molecular identity of 99 clinical isolates of the opportunistic fungal genus Curvularia. Diagnostic Microbiology and Infectious Disease 76, 168-174. 
da Cunha KC, Sutton DA, Gené J, Cano J et al. 2014 - Pithomyces species (Montagnulaceae) from clinical specimens: identification and antifungal susceptibility profiles. Medical Mycology $52,748-757$.

Damm U, Cannon PF, Liu F, Barreto RW et al. 2013 - The Colletotrichum orbiculare species complex: important pathogens of field and weeds. Fungal Diversity 61, 29-59.

Daranagama DA, Hyde KD, Sir EB, Thambugala KM et al. 2017 - Towards a natural classification and backbone tree for Graphostromataceae, Hypoxylaceae, Lopadostomataceae and Xylariaceae. Fungal Diversity, DOI 10.1007/s13225-017-0388-y

Dayarathne MC, Boonmee S, Braun U, Crous PW et al. 2016 - Taxonomic utility of old names in current fungal classification and nomenclature: Conflicts, confusion \& clarifications. Mycosphere 7, 1622-1648.

Devi P, Rodrigues C, Naik CG, D'Souza L. 2012 - Isolation and characterization of antibacterial compound from a mangrove-endophytic fungus, Penicillium chrysogenum MTCC 5108. Indian Journal of Microbiology 52, 617-623.

Dissanayake AJ, Zhang W, Liu M, Hyde KD et al. 2017 - Diaporthe species associated with peach tree dieback in Hubei, China. Mycosphere 8(5), 533-549.

Doilom M, Dissanayake AJ, Wanasinghe DN, Boonmee S et al. 2017 - Microfungi on Tectona grandis (teak) in Northern Thailand. Fungal Diversity 82, 107-182.

Duke NC. 2006 - Rhizophora apiculata, $R$. mucronata, $R$. stylosa, $R . \times$ annamalai, $R . \times$ lamarckii (Indo-West Pacific stilt mangrove). Rhizophoraceae (mangrove family). Species Profiles for Pacific Island Agroforestry. www.traditionaltree.org (accessed 27 November 2017).

Floudas D, Hibbett DS. 2015 - Revisiting the taxonomy of Phanerochaete (Polyporales, Basidiomycota) using a four gene dataset and extensive ITS sampling. Fungal Biology 119, 679-719.

Fröhlich J, Hyde KD, Petrini O. 2000 - Endophytic fungi associated with palms. Mycological Research 104, 1202-1212.

Gadagkar SR, Rosenberg MS, Kumar S. 2005 - Inferring species phylogenies from multiple genes: concatenated sequence tree versus consensus gene tree. Journal of Experimental Zoology Part B: Molecular and Developmental Evolution 304B, 64-74.

Gazis R, Rehner S, Chaverri P. 2011 - Species delimitation in fungal endophyte diversity studies and its implications in ecological and biogeographic inferences. Molecular Ecology 20, 3001-3013.

Glienke C, Pereira O, Stringari D, Fabris J et al. 2011 - Endophytic and pathogenic Phyllosticta species, with reference to those associated with Citrus black spot. Persoonia 26, 47-56.

Gomes RR, Glienke C, Videira SIR, Lombard L et al. 2013 - Diaporthe: a genus of endophytic, saprobic and plant pathogenic fungi. Persoonia 31, 1-41.

Guarnaccia V, Groenewald JZ, Li H, Glienke C et al. 2017 - First report of Phyllosticta citricarpa and description of two new species, $P$. paracapitalensis and $P$. paracitricarpa, from citrus in Europe. Studies in Mycology 87, 161-185.

Guo LD, Hyde KD, Liew ECY. 1998 - A method to promote sporulation in palm endophytic fungi. Fungal Diversity 1, 109-113.

Guo LD, Hyde KD, Liew ECY. 2000 - Identification of endophytic fungi from Livistona chinensis based on morphology and rDNA sequences. The New Phytologist 147, 617-630.

Guo LD, Hyde KD, Liew ECY. 2001 - Detection and taxonomic placement of endophytic fungi within frond tissues of Livistona chinensis based on rDNA sequences. Molecular Phylogenetics and Evolution 20, 1-13.

Guo LD, Huang GR, Wang Y, He WH et al. 2003 - Molecular identification of white morphotype strains of endophytic fungi from Pinus tabulaeformis. Mycological Research 107, 680-688.

Haghighi MT, Shahdoust E. 2015 - Molecular detection of endophytic, Myrothecium spp. by ITSsequencing technique. International Journal of Research Studies in Biosciences 3(1), 60-66.

Hall TA. 1999 - BioEdit: a user-friendly biological sequence alignment editor and analysis program for Windows 95/98/NT. Nucleic Acids Symposum Series 41, 95-98. 
Harty C. 1997 - Mangrove in New South Wales and Victoria: forests of the tidal zone in terperate Australia. Vista Publication, Melbourne, Australia.

Hyde KD, Bussaban B, Paulus B, Crous PW et al. 2007 - Biodiversity of saprobic fungi. Biodiversity and Conservation 16, 17-35.

Hyde KD, Soytong K. 2008 - The fungal endophyte dilemma. Fungal Diversity 33, 163-173.

Hyde KD, Cai L, McKenzie EHC, Yang YL et al. 2009 - Colletotrichum: a catalogue of confusion. Fungal Diversity 39, 1-17.

Hyde KD, Nilsson RH, Alias SA, Ariyawansa HA et al. 2014 - One stop shop: backbones trees for important pytopathogenic genera: I. Fungal Diversity 67, 21-125.

Hyde KD, Hongsanan S, Jeewon R, Bhat DJ et al. 2016 - Fungal diversity notes 367-490: taxonomic and phylogenetic contributions to fungal taxa. Fungal Diversity 81, 1-270.

Hu HL, Jeewon R, Zhou DQ, Zhou TX, Hyde KD. 2007 - Phylogenetic diversity of endophytic Pestalotiopsis species in Pinus armandii and Ribes spp.: evidence from rDNA and $\beta$-tubulin gene phylogenies. Fungal Diversity 24, 1-22.

Huang WY, Cai YZ, Surveswaran S, Hyde KD et al. 2009 - Molecular phylogenetic identification of endophytic fungi isolated from three Artemisia species. Fungal Diversity 36, 69-88.

Jayawardena RS, Hyde KD, Damm U, Cai L et al. 2016 - Notes on currently accepted species of Colletotrichum. Mycosphere 7, 1192-1260.

Jeewon R, Liew ECY, Hyde KD. 2002 - Phylogenetic relationships of Pestalotiopsis and allied genera inferred from ribosomal DNA sequences and morphological characters. Molecular Phylogenetics and Evolution 25, 378-392.

Jeewon R, Liew ECY, Simpson JA, Hodgkiss IJ, Hyde KD. 2003 - Phylogenetic significance of morphological characters in the taxonomy of Pestalotiopsis species. Molecular Phylogenetics and Evolution 27, 372-383.

Jeewon R, Liew ECY, Hyde KD. 2004 - Phylogenetic evaluation of species nomenclature of Pestalotiopsis in relation to host association. Fungal Diversity 17, 39-55.

Jeewon R, Ittoo J, Mahadeb D, Jaufeerally-Fakim Y et al. 2013 - DNA based identification and phylogenetic characterisation of endophytic and saprobic fungi from Antidesma madagascariense, a medicinal plant in Mauritius. Journal of Mycology 781914, 1-10.

Jeewon R, Hyde KD. 2016 - Establishing species boundaries and new taxa among fungi: recommendations to resolve taxonomic ambiguities. Mycosphere 7, 1669-1677.

Job N, Manomi S, Philip R. 2015 - Isolation and characterisation of endophytic fungi from Avicennia officinalis. International Journal of Research in Biomedicine and Biotechnology 5, 4-8.

Joel EL, Bhimba BV. 2012 - Fungi from mangrove plants: their antimicrobial and anticancer potentials. International Journal of Pharmacy and Pharmaceutical Sciences 4, 139-142.

Kang S, Mansfield MA, Park B, Geiser DM et al. 2010 - The promise and pitfalls of sequencebased identification of plant pathogenic fungi and oomycetes. Phytopathology 100, 732-737.

Khamchatra N, Dixon KW, Tantiwiwat S, Piapukiew J. 2016 - Symbiotic seed germination of an endangered epiphytic slipper orchid, Paphiopedilum villosum (Lindl.) Stein. from Thailand. South African Journal of Botany 104, 76-81.

Ko TWK, Stephenson SL, Bahkali AH, Hyde KD. 2011 - From morphology to molecular biology: can we use sequence data to identify fungal endophytes? Fungal Diversity 50, 113-120.

Kornerup A, Wanscher JH. 1967 - Methuen Handbook of Colour, $2^{\text {nd }}$ edn. Methuen \& Co. London, England.

Kuhnert E, Fournier J, Peršoh D, Luangsa-ard JJD, Stadler M. 2014a - New Hypoxylon species from Martinique and new evidence on the molecular phylogeny of Hypoxylon based on ITS rDNA and $\beta$-tubulin data. Fungal Diversity 64, 181-203.

Kuhnert E, Heitkämper S, Fournier J, Surup F, Stadler M. 2014b - Hypoxyvermelhotins A - C, new pigments from Hypoxylon lechatii sp. nov. Fungal Biology 118, 242-52.

Kumar DSS, Hyde KD. 2004 - Biodiversity and tissue-recurrence of endophytic fungi in Tripterygium wilfordii. Fungal Diversity 17, 69-90. 
Lacap DC, Hyde KD, Liew ECY. 2003 - An evaluation of the fungal 'morphotype' concept based on ribosomal DNA sequences. Fungal Diversity 12, 53-66.

Lian Y, Xu J, Lin P, Meguro S, Kawachi S. 1999 - Five heavy metals in propagules of ten mangrove species of China. Journal of Wood Science 45, 343-347.

Lindahl BD, Nilsson RH, Tedersoo L, Abarenkov K et al. 2013 - Fungal community analysis by high- throughput sequencing of amplified markers-a user's guide. New Phytologist 199, 288-299.

Liu SL, He SH. 2016 - Phanerochaete porostereoides, a new species in the core clade with brown generative hyphae from China. Mycosphere 7, 648-655.

Maharachchikumbura SSN, Guo LD, Chukeatirote E, Bahkali AH, Hyde KD. 2011 Pestalotiopsis - morphology, phylogeny, biochemistry and diversity. Fungal Diversity 50, 167-187.

Maharachchikumbura SSN, Guo LD, Cai L, Chukeatirote E et al. 2012 - A multi-locus backbone tree for Pestalotiopsis, with a polyphasic characterization of 14 new species. Fungal Diversity $56,95-129$.

Maharachchikumbura SSN, Hyde KD, Groenewald JZ, Xu J, Crous PW. 2014 - Pestalotiopsis revisited. Studies in Mycology 79, 121-186.

Maharachchikumbura SSN, Larignon P, AL-SADI AM, Zuo-Yi L. 2016 - Characterization of Neopestalotiopsis, Pestalotiopsis and Truncatella species associated with grapevine trunk diseases in France. Phytopathologia Mediterranea 55, 380-390.

Mangroves for the Future (MFF) 2011 - National Strategy and Action Plan 2011 - 2013. Thailand, Bangkok, 1-67.

Miller MA, Pfeiffer W, Schwartz T. 2010 - Creating the CIPRES science gateway for inference of large phylogenetic trees. In Proceedings of the Gateway Computing Environments Workshop (GCE). San Diego Supercomput. Center, New Orleans, 1-8.

Mirarab S, Bayzid MS, Warnow T. 2016 - Evaluating summary methods for multilocus species tree estimation in the presence of incomplete lineage sorting. Systematic Biology 65, 366380.

Nayak SS, Gonsalves V, Nazareth SW. 2012 - Isolation and salt tolerance of halophilic fungi from mangroves and solar salterns in Goa-India. Indian Journal of Geo-Marine Sciences 41, 164 172.

Nilsson RH, Kristiansson E, Ryberg M, Hallenberg N, Larsson KH. 2008 - Intraspecific ITS variability in the kingdom Fungi as expressed in the international sequence databases and its implications for molecular species identification. Evolutionary Bioinformatics Online 4, 193 201.

Nilsson RH, Hyde KD, Pawłowska J, Ryberg M et al. 2014 - Improving ITS sequence data for identification of plant pathogenic fungi. Fungal Diversity 67, 11-19.

Nocker A, Burr M, Camper K. 2007 - Genotypic microbial community profiling: a critical technical review. Microbial Ecology 54, 276-289.

Okane I, Srikitikulchai P, Tabuchi Y, Sivichai S, Nakagiri A. 2012 - Recognition and characterization of four Thai xylariaceous fungi inhabiting various tropical foliages as endophytes by DNA sequences and host plant preference. Mycoscience 53(2), 122-132.

Page RDM. 1996 - TreeView: an application to display phylogenetic trees on personal computers. Computer Applications in the Biosciences 12, 357-358.

Paul NC, Deng JX, Shin KS, Yu SH. 2012 - Molecular and morphological characterization of endophytic Heterobasidion araucariae from roots of Capsicum annuum L. in Korea. Mycobiology 40, 85-90.

Petrini O. 1991 - Fungal endophytes of tree leaves. In Andrews JH, Hirano SS (eds.). Microbial Ecology of Leaves. Springer, New York, 179-197.

Photita W, Lumyong S, Lumyong P, Hyde KD. 2001 - Endophytic fungi of wild banana (Musa acuminata) at Doi Suthep Pui National Park, Thailand. Mycological Research 105(12), 15081513. 
Photita W, Lumyong S, Lumyong P, McKenzie EHC, Hyde KD. 2004 - Are some endophytes of Musa acuminata latent pathogens? Fungal Diversity 16, 131-140.

Promputtha I, Jeewon R, Lumyong S, McKenzie EHC, Hyde KD. 2005 - Ribosomal DNA fingerprinting in the identification of non-sporulating endophytes from Magnolia liliifera (Magnoliaceae). Fungal Diversity 20, 167-186.

Promputtha I, Lumyong S, Dhanasekaran V, McKenzie EHC et al. 2007 - A phylogenetic evaluation of whether endophytes become saprotrophs at host senescence. Microbial Ecology 53, 579-590.

Ravikumar S, Williams GP, Shanthy S, Gracelin NA et al. 2007 - Effect of heavy metals (Hg and $\mathrm{Zn}$ ) on the growth and phosphate solubilising activity in halophilic phosphobacteria isolated from Manakudi mangrove. Journal of Environmental Biology 28, 109-114.

Rodriguez RJ, Redman RS, Henson JM. 2004 - The role of fungal symbioses in the adaptation of plants to high stress environments. Mitigation and Adaptation Strategies for Global Change 9, 261-272.

Ronquist F, Huelsenbeck J, Teslenko M. 2011 - Draft MrBayes version 3.2 manual: tutorials and model summaries. Distributed with the software from http://brahms. biology. rochester. edu/software. html.

Saikkonen K, Saari S, Helander M. 2010 - Defensive mutualism between plants and endophytic fungi?. Fungal Diversity 41, 101-113.

Sakayaroj J, Preedanon S, Supaphon O, Jones EBG, Phongpaichit S. 2010 - Phylogenetic diversity of endophyte assemblages associated with the tropical seagrass Enhalus acoroides in Thailand. Fungal Diversity 42, 27-45.

Santos J, Phillips AJL. 2009 - Resolving the complex of Diaporthe (Phomopsis) species occurring on Foeniculum vulgare in Portugal. Fungal Diversity 34, 111-125.

Santos L, Alves A, Alves R. 2017 - Evaluating multi-locus phylogenies for species boundaries determination in the genus Diaporthe. Peer J 5, e3120.

Schoch CL, Seifert KA, Huhndorf S, Robert V et al. 2012 - Nuclear ribosomal internal transcribed spacer (ITS) region as a universal DNA barcode marker for Fungi. Proceedings of the National Academy of Sciences 109, 6241-6246.

Schoch CL, Robbertse B, Robert V, Vu D et al. 2014 - Finding needles in haystacks: linking scientific names, reference specimens and molecular data for Fungi. Database 2014(bau061), $1-21$.

Sieber TN. 2007 - Endophytic fungi in forest trees: are they mutualists? Fungal Biology Reviews $21,75-89$.

Siqueira JPZ, Sutton D, Gené J, García D et al. 2016 - Schizophyllum radiatum, an emerging fungus from human respiratory tract. Journal of Clinical Microbiology 54, 2491-2497.

Slippers B, Wingfield MJ. 2007 - Botryosphaeriaceae as endophytes and latent pathogens of woody plants: diversity, ecology and impact. Fungal Biology Reviews 21, 90-106.

Stefani FOP, Bell TH, Marchand C, de la Providencia IE et al. 2015 - Culture-dependent and independent methods capture different microbial community fractions in hydrocarboncontaminated soils. PLoS ONE 10, e0128272.

Sun X, Guo LD, Hyde KD. 2011 - Community composition of endophytic fungi in Acer truncatum and their role in decomposition. Fungal Diversity 47, 85-95.

Talhinhas P, Sreenivasaprasad S, Neves-Martins J, Oliveira H. 2002 - Genetic and morphological characterization of Colletotrichum acutatum causing anthracnose of lupins. Phytopathology 92, 986-996.

Tang AMC, Jeewon R, Hyde KD. 2007 - Phylogenetic relationships of Nemania plumbea sp. nov. and related taxa based on ribosomal ITS and RPB2 sequences. Mycological Research 111, 392-402.

Tang AMC, Jeewon R, Hyde KD. 2009 - A re-evaluation of the evolutionary relationships within the Xylariaceae based on ribosomal and protein-coding gene sequences. Fungal Diversity 34, 127-155. 
Tao G, Liu ZY, Liu F, Gao YH, Cai L. 2013 - Endophytic Colletotrichum species from Bletilla ochracea (Orchidaceae), with description of seven new species. Fungal Diversity 61, 139164.

Taylor LE, Hyde KD, Jones EBG. 1999 - Endophytic fungi associated with the temperate palm Trachycarpus fortune $i$ within and outside its natural geographic range. New Phytologist 142, 335-346.

Tejesvi MV, Kajula M, Mattila S, Pirttilä AM. 2011 - Bioactivity and genetic diversity of endophytic fungi in Rhododendron tomentosum Harmaja. Fungal Diversity 47, 97-107.

Thirunavukkarasu N, Suryanarayanan TS, Murali TS, Ravishankar JP, Gummadi SN. 2011 - Lasparaginase from marine derived fungal endophytes of seaweeds. Mycosphere 2(2), 147155.

Thrush SF, Townsend M, Hewitt JE, Davies K et al. 2013 - The many uses and values of estuarine ecosystems. In Dymond JR (ed.). Conditions and trends. Ecosystem services in New Zealand, Manaaki Whenua Press, Lincoln, New Zealand.

Udayanga D, Liu X, Crous PW, McKenzie EHC et al. 2012 - A multi-locus phylogenetic evaluation of Diaporthe (Phomopsis). Fungal Diversity 56, 157-171.

Udayanga D, Castlebury LA, Rossman AY, Hyde KD. 2014a - Species limits in Diaporthe: molecular re-assessment of $D$. citri, $D$. cytosporella, $D$. foeniculina and $D$. rudis. Persoonia $32,83-101$.

Udayanga D, Castlebury LA, Rossman LA, Chukeatirote E, Hyde KD. 2014b - Insights into the genus Diaporthe: phylogenetic species delimitation in the D. eres species complex. Fungal Diversity 64, 203-229.

Vaz ABM, Fonseca PLC, Leite LR, Badotti F et al. 2017 - Using next-generation sequencing (NGS) to uncover diversity of wood-decaying fungi in neotropical Atlantic forests. Phytotaxa 295, 1-21.

Vaz-Moreira I, Egas C, Nunes OC, Manaia CM. 2011 - Culture-dependent and culture-independent diversity surveys target different bacteria: a case study in a freshwater sample. Antonie van Leeuwenhoek 100(2), 245-257.

Weir BS, Johnston PR, Damm U. 2012 - The Colletotrichum gloeosporioides species complex. Studies in Mycology 73, 115-180.

White TJ, Bruns T, Lee S, Taylor J. 1990 - Amplification and direct sequencing of fungal ribosomal RNA genes for phylogenetics. In Innis MA, Gelfand DH, Sninsky JJ, White TJ (eds.). PCR Protocols: A Guide to Methods and Applications. Academic Press, San Diego, 315-322.

Wicht B, Petrini O, Jermini M, Gessler C, Broggini GAL. 2012 - Molecular, proteomic and morphological characterization of the ascomycete Guignardia bidwellii, agent of grape black rot: a polyphasic approach to fungal identification. Mycologia 104, 1036-1045.

Wikee S, Lombard L, Nakashima C, Motohashi K et al. 2013a - A phylogenetic re-evaluation of Phyllosticta (Botryosphaeriales). Studies in Mycology 76, 1-29.

Wikee S, Lombard L, Crous PW, Nakashima C et al. 2013b - Phyllosticta capitalensis, a widespread endophyte of plants. Fungal Diversity 6, 91-105.

Wong MH, Crous PW, Henderson J, Groenewald JZ, Drenth A. 2012 - Phyllosticta species associated with freckle disease of banana. Fungal Diversity 56, 173-187.

Wulandari N, To-Anun C, Hyde KD, Duong L et al. 2009 - Phyllosticta citriasiana sp. nov., the cause of Citrus tan spot of Citrus maxima in Asia. Fungal Diversity 34, 23-39.

Yoo JJ, Eom AH. 2012 - Molecular identification of endophytic fungi isolated from needle leaves of conifers in Bohyeon Mountain, Korea. Mycobiology 40, 231-235. 